\title{
The Hidden Landscape of Prehistoric Greece
}

\section{John Bintliff ${ }^{1}$, Phil Howard ${ }^{2}$ and Anthony Snodgrass ${ }^{3}$}

${ }^{1}$ Faculteit der Archeologie, Universiteit Leiden, Postbus 9515, 2300 RA Leiden, The Netherlands

${ }^{2}$ Archaeology Department, University of Durham, South Road, Durham DH1 3LE, United Kingdom

${ }^{3}$ Faculty of Classics, University of Cambridge, Sidgwick Avenue, Cambridge CB3 9DA, United Kingdom

\begin{abstract}
For all-period intensive surveys in Greece, even those of very recent years, an abiding problem has been the difficulty of detecting prehistoric remains, whether at the level of nucleated sites or in the form of scatters across the landscape. The authors suggest explanations for the problems encountered in this regard, over the past 20 years, by the Boeotia Survey. They offer some first steps towards the solution of these problems, based on a reassessment of the actual results achieved, here and elsewhere, by intensive survey methods.
\end{abstract}

\section{Introduction}

When we first embarked, in 1979, on intensive survey in Boeotia, Central Greece (Figure 1), we were joining a tradition with a decided prehistoric bias. Of the pioneer archaeological surface surveys of Greek lands in modern times that were our models, Messenia (McDonald and Rapp 1972) was designed primarily to reveal, in unprecedented detail, the later prehistoric landscapes in its chosen region, while Melos (Cherry 1982; Wagstaff and Cherry 1982) ran concurrently with the excavation of the Late Bronze Age site at Phylakopi on the same island. Boeotia, however, belonged to a younger generation of field surveys-Keos, Nemea, Methana, Laconia-each of them inaugurated between 1979 and 1984. These were influenced by the trend in the United States, the leading source of survey theory, towards ever more intensive fieldwalking and recording of all traces of human activity, regardless of period. Newer surveys were thus unavoidably confronted by a dense mass of sites and 'offsite' finds, in which the artefacts of historic eras were dominant. The Argolid survey, begun 'unofficially' by Michael Jameson with a more traditional, topographic approach during the 1950s, but transformed into a fieldby-field, intensive survey by the early 1970 s (Jameson et al. 1994) had in fact already inaugurated an approach to the Greek landscape that did not privilege any one phase, but focused instead on the patterns of 'sequent occupance', right down to the present day. The same can be said of the Ayiofarango Survey in Crete, from the mid-1970s (Blackman and Branigan 1977).

Both in the Argolid and in the younger generation of surveys that followed, certain recurrent features became strikingly apparent in the relationship between the later prehistoric (Neolithic, Bronze Age and Early Iron Age) and the historical (Graeco-Roman, Mediaeval and Post-Mediaeval) occupancy of what was essentially the southern, lowland Greek landscape. Prehistoric settlement 'sites' 


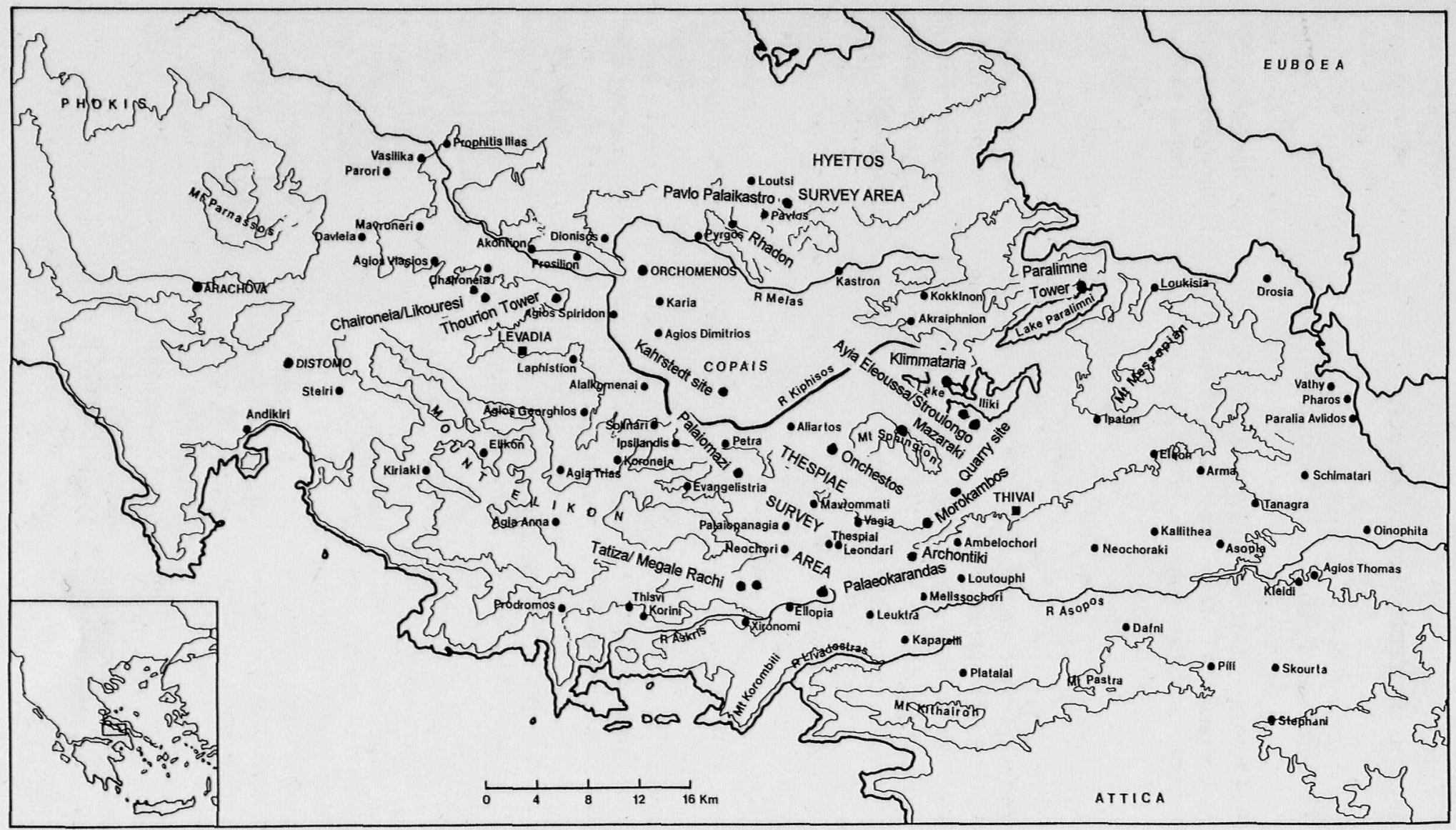

Figure 1. The province of Boeotia, Central Greece, showing the position of the two major areas covered by the Boeotia Survey Project (Thespiae district in the south-centre; Hyettos district in the northeast), modern villages, and archaeological locations studied by the Project outside these two survey zones. 
were notably less numerous by comparison with those of Graeco-Roman date, and for prehistory overall surface artefact densities were, for the most part, low. Demographically, it was difficult to believe that populations in these phases had ever been comparable with those that could be inferred from the infinitely more numerous remains of historic times. This aspect had been brought home very clearly in a revealing analysis of prehistoric sites from the Melos Survey by John Cherry $(1979 ; 1982)$. Here the numerous small sites scattered across the island, taken together with the likely occupation-span of each site and the millennia over which the total prehistoric site-complement had to be spread, made it unlikely that many of the small sites mapped were ever contemporary: the population at any one time, at least until the development of the first large nucleated village at Phylakopi by the Middle Bronze Age, was likely to have been tiny.

On the Boeotia survey, prehistoric 'sites' (that is, to take the generally cited definition, foci of surface artefacts that were dense by comparison with the local background level, and were assumed to mark former settlements, cemeteries or other areas of heightened human activity) were distributed widely-if thinly-across the entire surveyed area (by 1991, some 55 sq $\mathrm{km}$ covered by close-order pedestrian survey at normally $15 \mathrm{~m}$ fieldwalker intervals) (for the methodology, see Bintliff and Snodgrass 1985). But their numbers appeared to be so small and their distribution so patchy (only some 35 prehistoric sites identified across the entire surveyed area: Oliver Dickinson, pers. com.) that the inferences we had hoped to draw about population dynamics, variable uses of landscape, settlement networks and hierarchies were rapidly proved unattainable, especially as many of these sites were occupied in more than one prehistoric period. By contrast, such approaches were infinitely easier for the historical era, and it was a compensation for the two directors to exploit the seemingly inexhaustible database available from the surface finds of later periods, with the additional opportunities for linking them to archival and formal historical sources (Bintliff 1991; 1996; 1997a; 1997b; Bintliff and Snodgrass 1988b; Snodgrass 1987).

The Paradox: Intensive Survey and the Prehistoric Settlement Pattern

This was not what we had anticipated. One aspiration of the younger generation of 'intensive survey' project-leaders was to reveal the true density and complexity of the prehistoric Greek landscape. There was an explicit contrast with the picture (then widely considered to be misleading) given by the results from the 'extensive' approach exemplified by the Minnesota Messenia survey (McDonald and Rapp 1972), which had generated something of a cause célèbre within the circle of Mediterranean topographers and field survey practitioners. The University of Minnesota team had managed to survey a relatively vast region (some $3800 \mathrm{sq} \mathrm{km}$ ) through the selective visiting of 'promising' topographic features, believed from previous site discoveries to typify settlement locations during the Late Bronze Age (Mycenaean) era. Prior inspection of aerial photographs, together with local informants' knowledge of places where antiquities were prominent, had speeded up the task of identifying places to visit. Although to some extent the Minnesota field survey broke out of this mode of restricted visits to predetermined locations, the team's analysis of known sites, together with the results of all its new fieldwork, seemed to reinforce the view that later prehistoric communities in Messenia lived in small-to-medium nucleated settlements, largely in the same places, 
throughout the Bronze Age. Moreover, a favourable comparison of the catalogue of Late Bronze Age sites with the list of placenames in the Mycenaean palace archives at the regional centre of Pylos led to the suggestion that the majority of such settlements had indeed been identified, before and during the survey. The sum total of prehistoric sitessome 300 for the region studied-was however recognized to have been reduced by site burial in alluvial valleys and related processes, and was therefore tentatively adjusted to a figure closer to 400 (McDonald and Rapp 1972: 141).

The 'New Wave' of exponents of intensive survey in Greece now criticized, with all the vehemence of Young Turks, the failings of the Messenia model of 'extensive survey'. Sites not found in previously hypothesized 'favoured locations' would escape notice; small sites requiring close-order field-by-field walking would generally be ignored; and a predictable consequence of such traditional methods would be to locate only the larger settlements, occupied over a longer period, especially those where defensible positions on isolated hilltops allowed rapid, 'targeted' visits as the main approach to fieldwork (Bintliff 1977a; 1977b; Bintliff and Snodgrass 1985; Cherry 1983; 1984). Indeed, despite a spirited defence of the Minnesota approach on the part of its practitioners (Carothers and McDonald 1979; Hope-Simpson 1984; 1985; McDonald 1984), the post-Messenia 'intensive surveys' appeared to prove their point convincingly by discovering a vastly higher density of sites everywhere else in lowland Southern Greece than the 'extensive' approach had ever imagined-especially the small sites interpreted as farms (Classical Greek) and villas (Roman) (cf. Bintliff and Snodgrass 1985: table 4). For later prehistory, the multiplication of previously known sites through the field-by-field, close-order field- walking characteristic of these surveys (Argolid, Ayiofarango, Boeotia, Keos, Methana, Laconia) achieved a similar goal, with a site density many times greater than that provided by the Messenian statistics. To take the example already cited (above) of the Boeotia Project: 35 prehistoric 'sites' identified in some $55 \mathrm{sq} \mathrm{km}$ gives one site for every $1.6 \mathrm{sq}$ $\mathrm{km}$, whereas the Messenian density is 1 site for every $13 \mathrm{sq} \mathrm{km}$ (McDonald and Rapp 1972: 15). Here, intensive survey produced an eight-fold increase in prehistoric site density. Overall, the discrepancy is much greater: the Messenia total site density is 1 site in every $12 \mathrm{sq} \mathrm{km}$, while a typical intensive Greek survey finds some 4 sites in every 1 sq $\mathrm{km}$ - a differential of about 50 (Cherry 1983: fig. 1; Bintliff and Snodgrass 1985: 136).

But (and it is a big 'but') the pattern of prehistoric sites revealed was not so strikingly different from that claimed by the Messenia survey: in comparison with the GraecoRoman settlement density, there was a relatively thin scatter of genuinely small (farm?) sites, a small number of larger hamlet-village sites and, of course, the occasional semi-urban 'central place', the latter two often occupied through most periods of later prehistory and the historical eras. Any hopes of picking up fluctuations in settlement systems, with such continuity of the core nucleated sites, proved illusory: the very possibility of demonstrating, for example, population pressure, with such a poverty of prehistoric settlement size and numbers, disappeared. For certain parts of lowland Greece, it could be claimed that new models such as that of the Argolid team (Pope and van Andel 1984)-according to which widespread erosion was precipitated by Early Bronze Age settlement-depended on the detailed map for that phase achieved through intensive survey. But the geomorphology and its chronology could have stimulated the same interpretation, from the 
knowledge of Early Bronze Age settlement already obtained through prior study. Again, one might claim that the Melos survey could only have postulated its 'implosion' model (Cherry 1979; Wagstaff and Cherry 1982) for the decline of small rural sites across the Bronze Age and the rise of a single nucleated 'town' at Phylakopi, after the intensive survey of $20 \%$ of the island. But the excavations at Phylakopi, with a traditional study and revisit of the many prehistoric rural sites known prior to the intensive survey and their finds (cf. Bintliff 1977a: Part 2, Ch. 6), would have been adequate enough to generate the model proposed.

Very similar conclusions could be drawn from the reports of one of the latest intensive surveys from mainland Greece, the Pylos Regional Archaeological Project (Davis et al. 1997; Zangger et al. 1997; Davis 1998; cf. Shelmerdine 1997), which is appropriately set in the homeland of the original extensive Messenia survey of 30 years ago. Here, too, detailed survey has failed to provide evidence of a hitherto undiscovered multitude of small sites (whether for prehistory, or indeed even for the Classical age); on the contrary, the pattern of nucleated and long-lived sites, claimed by the Minnesota project for this region, appears to be confirmed. It is true that the overall site density, on the evidence of the preliminary reports on the Web (http://classics.lsa.umich.edu/PRAP.html) and in print (Davis et al. 1997; Davis 1998), has been increased by a factor of 2 to 2.5: but the increase is largely in sites of historical date, and most of the few new prehistoric sites also have historical occupation, underlining the thesis of persistence of locations. Genuinely small sites, of around 0.1 ha or less, remain a rarity for any period.

Perplexing as these findings may seem for the exponents of intensive survey, there are special factors that apply to the Messenian region in general, and the immediate vicinity of the Mycenaean palace at Pylos in particular. The latter had been, for obvious reasons, a scene of intensive research from the 1930s onwards: previous extensive surveys had achieved a prehistoric site density of 1 site per 3.3 sq $\mathrm{km}$-four times the density of the region as a whole-and the new Pylos Project has raised this figure to around 1 site per $2 \mathrm{sq}$ $\mathrm{km}$. This density is not so far from those recorded by intensive survey for prehistoric sites elsewhere-one site per $1.6 \mathrm{sq} \mathrm{km}$ in Boeotia, for example (the Pylos and Boeotia prehistoric site databases are still provisional, but in Shelmerdine's useful review [1997: 551] she lists for Early [EBA], Middle [MBA] and Late Bronze Age [LBA] sites, respectively, the figures of $6,1.1$ and 14 for the Pylos Survey, and 19, 16 and 16 for Boeotia, over not dissimilar areas).

A historical line of explanation might be sought for the fact that the density of sites of all periods in the Pylos district, even after intensive survey, stands at little more than 1 site per $\mathrm{sq} \mathrm{km}$, as compared with the density of about 4 sites per $\mathrm{sq} \mathrm{km}$ commonly found in intensive surveys elsewhere in Southern Greece. This can largely be accounted for by the absence of that explosion of small farm-sites in Archaic and Classical Greek times so prominent elsewhere-although that phenomenon is clearly detectable for the Messenian countryside at a later time, in the later Hellenistic and Roman periods. Already, in the Minnesota Project's volume of 1972, this pattern was seen as a predictable consequence of the prolonged Spartan occupation, which held back economic development in the region; and this reading was recently incorporated into a multiregional comparison (Bintliff 1997c) of Graeco-Roman demographic trends in the Aegean area.

There is also an important environmental contrast to be established between the Pylos area and certain other sectors of the Greek 
landscape, including (emphatically) central and western Boeotia. In the former district, the geomorphology showed unmistakable signs of serious erosion of the local marls (Zangger et al. 1997), which must have substantially affected the recovery of prehistoric sites and material. Boeotia, however, exemplifies a landscape that, though partly composed of similar marls, has remained (for Greece) unusually stable - a fact for which we have once again the authority of Eberhard Zangger (pers. comm.). As, however, two of us pointed out in a much earlier paper (Bintliff and Snodgrass 1988a), the effect of prehistoric and ancient erosion-excepting the rare cases of sites exposed on very steep slopes-is rather to concentrate surface artefact finds as 'lagged deposits' while preferentially removing the soil fines around them. Unless other factors were active (see below), one might expect that Messenian surface artefacts would be better exposed to view than those emanating from the more conserved palaeosols of Boeotia.

More positively, two highly significant features stand out from the admirably detailed preliminary publications and Internet Edition of the Pylos project: their importance will shortly become apparent. First, small numbers of prehistoric sherds frequently occur within collections from historical-period sites, the latter being clearly recognised by fieldwalkers as sites (or 'POSIs' to use their term) from the far more abundant historical surface occupation traces. Purely prehistoric sites are very rare, compared to historic sites where a minor prehistoric find component has also been recognized. In the (still incomplete) site gazetteer available on the Internet, definite prehistoric site occupation is approximately matched by findspots where the prehistoric pot or lithic component is so low as to be classified as probably non-site for each or at least one recognized prehistoric period. Sec- ondly, the Pylos team also found small numbers of prehistoric sherds at irregular points within normal transecting, not associated with clusters of any period. The maps so far available of prehistoric 'off-site' finds rest merely on a limited part of the potential prehistoric transect finds, those firmly dated (Sebastian Heath, pers. com.), so that the final distribution will be denser, but in our view the phenomenon of up to 20 such findspots per prehistoric phase merits close attention. With 17 and 20 'off-site' transect locations for the MBA and LBA, but only two for EBA, a strong contrast is suggested; but the decision not to collect undecorated coarseware body-sherds during fieldwalking (Davis et al. 1997: 401) in our view may well account for the contrast in identified findspots to the detriment of the Early Bronze Age, where surface ceramics are typically characterized by such sherds.

If the latest data from the Pylos Regional Archaeological Project can thus be argued to fall broadly into line with the site statistics from other intensive survey projects in southern Greece, it remains true that all such surveys have yielded a rather low representation of prehistoric sites. Quite apart from the general poverty of Neolithic settlements as one moves southwards from the tell landscapes of Thessaly, sites of Early, Middle and Late Bronze Age times are rarely single period; and they are neither sufficiently dense nor large enough to support any thesis of population even approaching local resource ceilings. Here we include the major centres, which bear no comparison with even a middle-ranking city-state of Classical Greek times (Bintliff 1997b). This remains true even if one assumes that known sites within a long prehistoric period were continuously occupied-which, as John Cherry cogently argued (1979), is unlikely to have been the case for the kind of hamlet, and rarely farm, settle- 
ments that almost all these sites represent.

The purpose of this article is to suggest, from the basis of our experience in Boeotia, that the history of research hitherto outlined-up to and including the latest results from the Pylos Project-rests upon an entirely false picture of the prehistoric landscape of southern lowland Greece. The shape of that landscape is of a totally different character from any map of prehistoric sites so far produced, or deployed in favour of competing demographic and settlement pattern models. Throughout this long debate over survey methods it has kept its secret-it has been a landscape hidden from our knowledge.

\section{Towards a Solution of the Problem}

The 20-year life of the Boeotia Survey has included a number of curious experiences. Three incidents remain firmly fixed in the memory, because they raised a spectre that seemed impossible to lay to rest. First, one of us (J.L.B) was leading half a dozen student field-walkers along the plateau rim above the ancient city of Thespiae (immediately south of the modern village of that name in the centre of Figure 1). We stopped transecting for a water-and-biscuits break, sitting athwart our transect route on lumps of conglomerate bedrock that had pierced the Tertiary marls in this locality. As the minutes passed, we became dully aware of some curious and poorly-defined anomalous shapes in the ploughsoil of the field immediately before us. They were like-coloured to the soil, and lacked the sharp, clear edges of normal ceramic sherds. We went to investigate. As we pulled the fragments out of their soil matrix, their texture was moist, soft and very fragile- 'wet biscuit' is an appropriate description. Later, however, they hardened in the dry summer heat and began to recover the shape and appearance of prehistoric coarseware. Careful gridded collection around the point of first discovery, which led to a significant enhancement of our prehistoric assemblage, later enabled us to demonstrate the existence of a 'site', with EBA and MBA phases, at this spot (PP19/20). It would almost certainly have eluded recognition if we had passed smoothly across it, observing only the typically high densities of historicalperiod ceramics that form a regular carpet around the large Graeco-Roman city of Thespiae. Perhaps a single piece of coarseware would have caught the eye of one fieldwalker; but, measured against the several hundred to several thousand sherds that are the statistical average for a $60 \times 50 \mathrm{~m}$ transect in this area of our survey (between $74 \%$ and $85 \%$ of them Classical-Hellenistic in date), no significance would have been given to that observation.

The second story has a similarly disconcerting flavour. We had observed that two ancient (Graeco-Roman) farmsites lay less than 50 . $60 \mathrm{~m}$ apart, in an area of olive groves a kilometre west of the ancient city. Were they merely a single large rural site with surface visibility problems in the intervening space? We resolved to revisit the spot: walking extremely slowly and carefully back and forth between the two previously recognized site areas, we were soon able to confirm that there was indeed a clear interval, lacking either higher densities of ancient ceramic or freshly broken material. At the same time, however, we again became aware of a new and hitherto unrecorded presence in this locality-precisely in the 'off-site' interval we began to see the 'wet-biscuit' shapes of prehistoric coarseware. Here we had walked and found historical sites, but had recorded nothing of this other-worldly scatter. Once more, the pieces concerned were very low in number and all but indistinguishable from the surrounding soil in colour, hardness and shape; once more, they were numerically swamped by the abundant ancient potsherds that surrounded them, but a prehistoric site (PP25) was in evidence 
nonetheless - as later intensive collection was to prove (with all three Bronze Age phases present).

The third story again arose from the discovery of an ancient, Graeco-Roman farmsite (MPA6), isolated, but rich in surface remains; this time it was perched in a small upland plateau above the Theban Plain near Onchestos (in the north of the Thespiae Survey Area of Figure 1). When the ceramics were catalogued and dated by our ceramic experts, a tiny collection - two or three pieces out of several hundred ancient sherds brought back as a sample - of MBA and LBA fineware was identified. Such is the relative scarcity of prehistoric sites in most intensive surveys that the discovery of a new exemplar is greeted with some excitement. As it happened, that year our prehistoric pot consultant, Chris Mee, was a Mycenaean specialist. Seized with enthusiasm, he set out for the site, only to spend fruitless hours on and around it in search of a single additional fragment. But if there was no site 'beneath' the ancient farm, or lurking close by, how could one account for the arrival of these pieces within the surface debris?

At this point, it should be observed that we in Boeotia had formed a conventional impression of what a prehistoric site ought to look like. Indeed, every season we had trained new field-walkers by taking them to our 'model behaviour' minor prehistoric site-Onchestos/ Kazarma on the low watershed where the Thebes-Livadheia road passes from the Theban Plain to the basin of the former Lake Copais. Here, although the diameter of the 'site' was modest (some $80 \mathrm{~m}$ - so not exactly small), we were always sure of collecting bagfuls of potsherds from all Bronze Age phasesand very little else. Of course Onchestos, with its ease of access, its striking topography, and that very quality of inexhaustible prehistoric surface material, had been spotted long before our survey began. In normal fieldwalking, absolute density changes were the primary means of identifying sites, but with our training of students to distinguish the less common wares, in lesser concentrations, which might signal a genuinely small prehistoric site or a historic burial location, we had still expected to correct an understandable discovery bias towards the more obvious kind of rich, focused prehistoric and historic sites.

What emerges from the stories just related? Most of the prehistoric pottery in our region was coarseware; it seemed to survive poorly and was hard to distinguish in the soil. The much more conspicuous wheel-made fine wares-Matt-painted, Minyan, Mycenaeanare easy to spot in excavated material, yet the hard fact is that we found them even less frequently than the hand-made 'wet biscuit' wares. Why was this? On the one hand, their numerical assemblage representation is far inferior to that of the coarser plainwares, and secondly, we have very frequently observed that once such fine wares erode out of subsurface deposits into recurrently turned ploughsoil, they soon lose much of their surface and distinctive contours-making them hard to separate at fieldwalker height from undiagnostic body-sherds. Further, since our region of Greece received very little obsidian, and the local chert looked similar to the regular stone content of the soils, we lacked another obvious means to compensate for the poor apparent showing of prehistoric ceramic clusters across the Boeotian land surface. To judge by the accidental discovery of such sites, after standard intensive fieldwalking had been unable to distinguish them, we had to face the fact that our survey was simply failing to detect their surface debris unless it formed quite dense concentrations. But could 'two or three sherds gathered together' constitute a case for the existence of a vestigial prehistoric site?

The explanation based on the increasing invisibility of prehistoric surface sites with age, 
even to intensive survey approaches, was a hypothesis that we had put forward tentatively in preliminary publications on the Boeotia survey (Bintliff and Snodgrass 1985: 137-38; Bintliff 1985: 214-15). We emphasize surface ceramic scatters, because it is precisely in the effect of surface exposure to mechanical and chemical breakdown, through cultivation and the weather, that ploughsoil assemblages stand to diminish rapidly in comparison to those revealed in excavated levels. This concept drew support from suspicions voiced by another prehistoric Aegean ceramicist (Rutter 1983), concerning the poor 'visibility properties' of certain prehistoric periods, leading as a consequence to an inadequate record of sites from those periods. At the same time, we became aware of a close parallel between observations made from surface survey in Italy, and one of the characteristic phenomena of our site collections. In Boeotia we not infrequently found that a welldefined ancient or mediaeval site, like that mentioned in the third story above, revealed, after gridding and sampling, a small number of prehistoric potsherds in among its plentiful historic assemblage. How was one to interpret this phenomenon? Di Gennaro and Stoddart (1982) reported the same from their re-examination of the vast find-collection from the area of the South Etruria Survey, north of Rome. As in Boeotia, targeted revisiting and re-study of the collections of a number of historic sites, each with a seemingly insignificant additional component of putative prehistoric material, had revealed a number of unsuspected prehistoric sites; closer inspection of the finds and the sites elevated the small prehistoric component still further, although total recognized numbers were far inferiot to those of the historical material. Back in Greece, in a sophisticated treatment of the Keos Survey surface assemblages, Cherry et al. (1991: 222-23, fig. 9.7) have also illustrated statistically the way in which prehistoric surface finds suffer adverse discrimination, in a landscape dominated by far denser clusters and off-site spreads of historical ceramics.

A good example of this type of site is our ' $\mathrm{Val}$ ley of the Muses 2' location (this district lies in the western part of the Thespiae Survey Area on Figure 1, directly west of Palaeopanagia village). Figure 2 (upper) shows the density of surface ceramics recorded on the site grid after visibility correction (i.e. multiplying up the raw number of sherds seen and counted by the estimated percentage of bare soil visible), as well as (lower left) the complete dominance of closelydatable sherds from the Archaic-Early Hellenistic period in the small sample (138) of ceramics taken from the site. The clearly focused distribution for the latter phase points to the likely position of a farmhouse structure on the east side of the grid. In scale and surface ceramic density, this is characteristic of the ubiquitous type of Classical rural site argued to represent a 'family farm'. Also in Figure 2 (lower right), however, we see that, associated with the dominant occupation phase, there is a small cluster of LBA pottery, only recognized during the laboratory study of the sample collection. Beyond doubt, this was also a local focus of Mycenaean activity; the scant finds in the sample collected (10 Mycenaean sherds against a total of 53 for the main historical period) probably reflect the impoverished fraction remaining in the ploughsoil from a farmhouse of similar scale and population to the later historic 'family-scale' farm site. Had we not identifed an ancient farm in the same location, it is statistically very likely that the earlier cluster would have entirely escaped notice when the fieldwalkers passed over the locality.

If an interpretation along these lines is accepted, then our site maps of prehistoric Greece may well be so far from past reality as to undermine the many models based on them-in particular, those concerned with the distribution and scale of population. Merely to recognize the possible existence of 
the 'hidden landscape' of our title, however, may reveal a failing on the part of recent intensive surveys in Greece for the prehistoric era (our own included), without providing a way forward in dealing with the problem.

The case of the large Graeco-Roman and
Mediaeval village of Askra in the Valley of the Muses is especially illuminating as a contrast to such almost invisible prehistoric sites as PP19/20, PP25, MPA6 and VM2, though it is the latter which may nevertheless represent the normal pattern in southern Greece. At

Visibility-corrected total density of surface ceramics

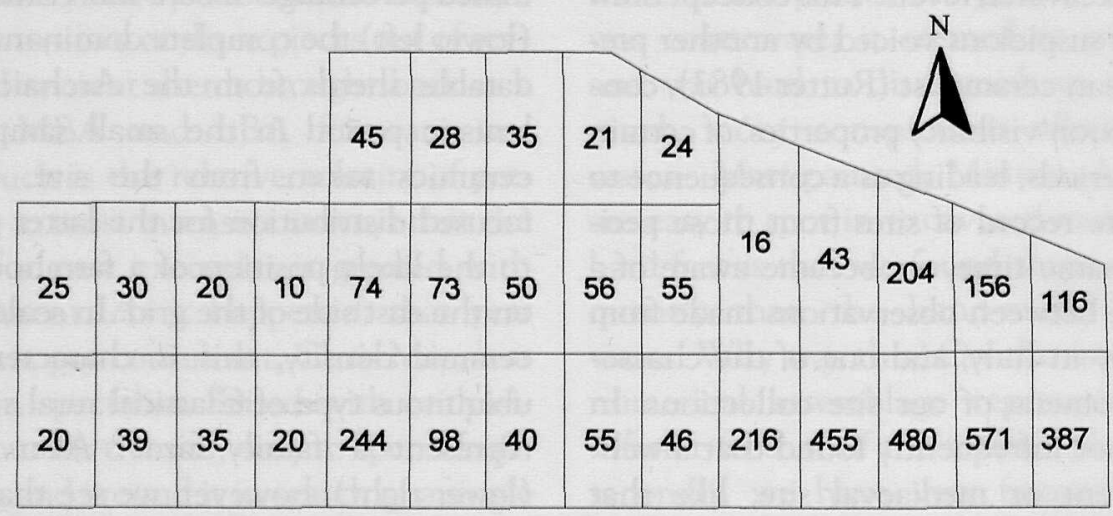

$\begin{array}{lllll}0 & 5 & 10 & 15 & \text { Meters }\end{array}$

Sample collection dated by period $(\mathrm{N}=138)$

a-ehl

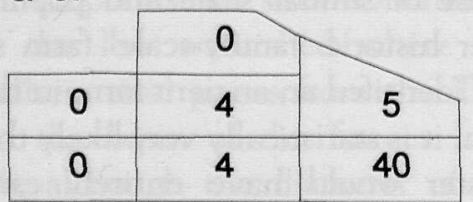

Ih

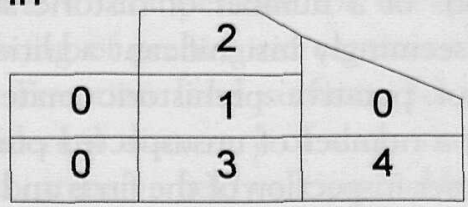

\section{$\begin{array}{llll}0 & 10 & 20 & 30 \\ & \text { Meters }\end{array}$}

Figure 2. Boeotia Survey, Valley of the Muses site 2. (Above) total surface pottery density (visibility-corrected count across the site grid). (Below) distribution of finds from a small sample collection made for dating $(n=138)$ : lower left, Archaic-Hellenistic (a-ehl) finds, the dominant phase; lower right, LBA (lh) finds. 
Askra, in the Classical period and then again in Late Roman times, datable ceramics indicate a maximal expansion of the site, which at some 11 ha could have contained over 1000 people (Bintliff 1997b). Yet the distribution of EBA ceramics is also quite extensive, as our on-going analysis has shown. Apart from small quantities found over the whole site (under 3\% of the total site sample collected for all periods), the northwest sector has a nucleus of some 2-3 ha, where prehistoric sherds comprise over $40 \%$ of the sample collected in that area. There was no risk whatever of such a concentration being missed. Here then is a traditional 'prehistoric settlement', whose size and artefactual density divert attention from the far more widespread, minimal-density prehistoric sites that may lie all around it in the Valley of the Muses, almost all of which we now believe to have eluded our intensive field-by-field survey of the district - unless, like VM2, they happen to lie beneath the more visible scatters of historical sites.

\section{Windows on the Hidden Prehistoric Land- scape of Southern Greece}

Three main propositions emerge from the argument so far, based on our experience of survey in Boeotia:

1. Generally, only the larger, multi-phase prehistoric sites achieve immediate recognition, through both extensive and intensive survey, and hence constitute the present 'prehistoric site database' and the model for what such a site should look like in the field.

2. Secondly, by unintentional and indirect means, one may come to suspect the presence of a hidden multitude of smaller, less continuously occupied sites-either through the kind of serendipitous discovery related above, or from the repeated experience of finding small numbers of prehistoric sherds among the pottery samples from highly visible historic sites.

3. Among the causes for this situation are the poorer survival potential, in ploughsoils as continuously cultivated as those of Boeotia, of prehistoric ceramic-most of it coarseware; the much longer period over which taphonomic processes have operated to destroy the greater part of it, and reduce the remainder to poorly recognizable, low density patches across the plough-soil surface; finally, and perhaps especially in Boeotia, the swamping of the landscape by very high densities of historical, sherds, making it almost impossible to detect or note as potentially diagnostic these small elements through standard fieldwalking, especially when they have been reduced to barely visible or invisible body-sherds.

The chance revelation in the field of what are probably the more typical, but vestigial, sites, is too rare an event to constitute a viable means of evaluating the scale of 'hidden' prehistoric settlement. An initial step towards producing a more realistic prehistoric map can be achieved through a retrospective upgrading of the seemingly insignificant collections of prehistoric sherds from later, higher-density sites. Rather than taking these tiny scatters at face value-which is what led Jacobsen (1984: 33), for example, to suggest that the small clusters of Neolithic activity traces at the ancient sanctuary of the Argive Heraeum testified to seasonal pastoralism rather than permanent settlement-we would wish to argue that such vestigial surface traces are all that we would expect from a typical small prehistoric settlement, particularly one prone to heavy weathering and massive later reoccupation. But here again, this is merely to detect a symptom of a potentially far larger phenomenon, biased by the coincidence of 
prehistoric settlements or other activity foci with historic settlement sites. We wish to suggest a more powerful means, one less dependent on sheer chance or the association with later occupation-sites, of recapturing the geographic scale and frequency of prehistoric occupation in lowland Greece.

Figure 3 displays one of two districts within the area surveyed by the Boeotia Project, where from 1989 onwards the field teams not only carried out our standard procedure of recording surface sherd density for every transect walked, together with surface visibility, but also collected a sample of the datable surface material from 'off-site' areas. The field-walkers, surveying a $2 \mathrm{~m}$ wide strip at $15 \mathrm{~m}$ intervals between walkers, and recording a count of every visible artefact, were also instructed to collect a small sample of such sherds as appeared especially diagnostic for dating (feature sherds, varied fabric and decoration types). The district shown, the Leondari-Southeast and Thespiae-South transect block, comprises some $5.2 \mathrm{sq} \mathrm{km}$ immediately abutting the walls of the ancient

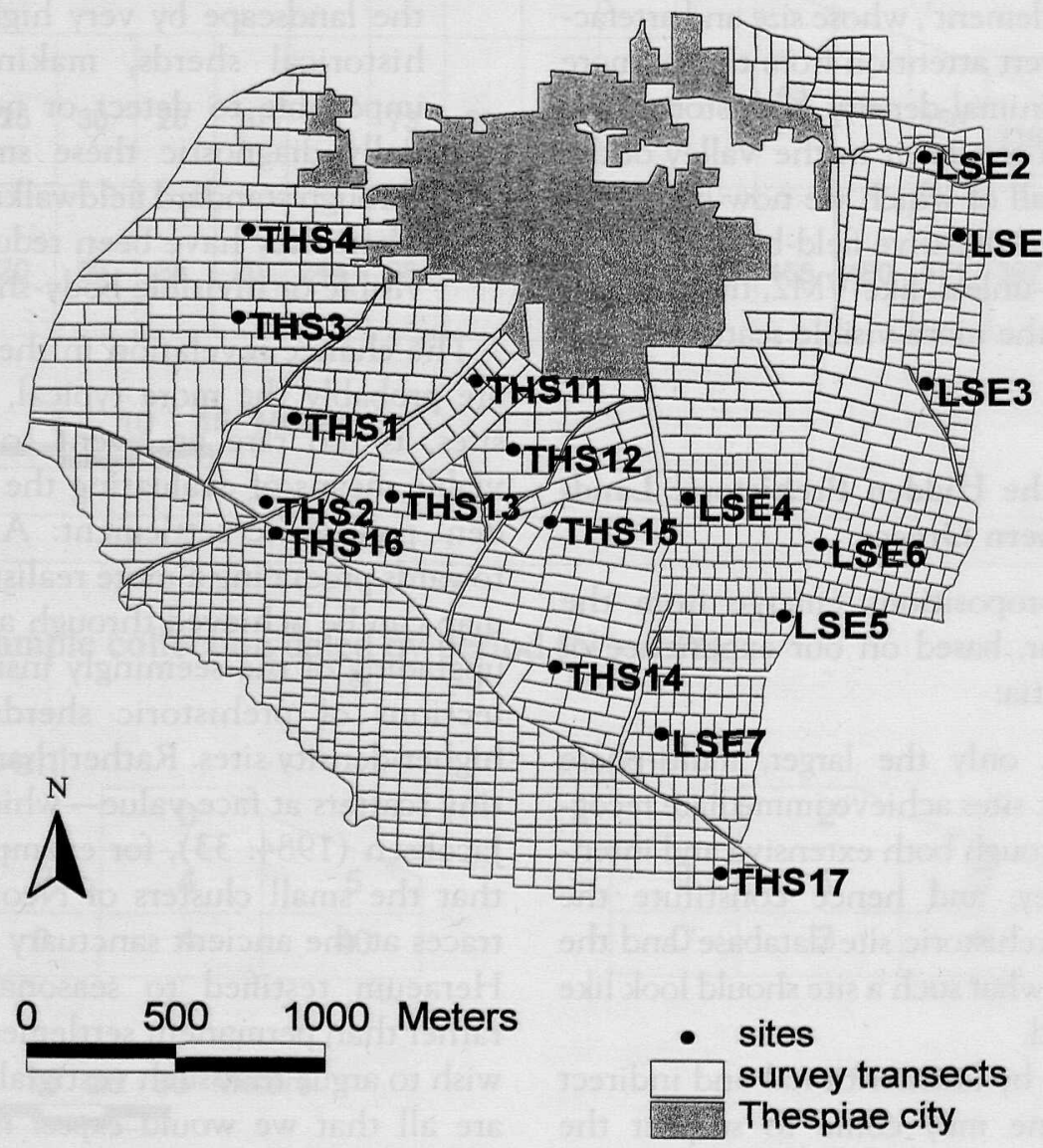

Figure 3. Fieldwalking transects in the LSE/THS sectors, adjacent to the ancient city of Thespiae, an area of 5.2 $\mathrm{sq} \mathrm{km}$. The location of the 18 rural sites identified during total fieldwalking of these sectors is indicated, with the area of the survey grid over the city in grey. 
city of Thespiae (the city lies north of the transects and its southern perimeter is enclosed by them on three sides, and is itself just south of the modern village of Thespiae marked on Figure 1). Displayed on the transect map are the location of the 18 small rural sites identified during the fieldwalking of this district. From subsequent analysis, one of these, at first believed to be a potential historic site, was later dismissed as a 'non-site'; all the rest are GraecoRoman, one having Mediaeval settlement evidence too; but none had more than a small scatter of prehistoric lithics or ceramics, and we thus have no official 'prehistoric sites' in this area.

Figure 4 maps 46 prehistoric lithic finds from the sample of surface artefacts brought back by fieldwalkers from the transects of this district
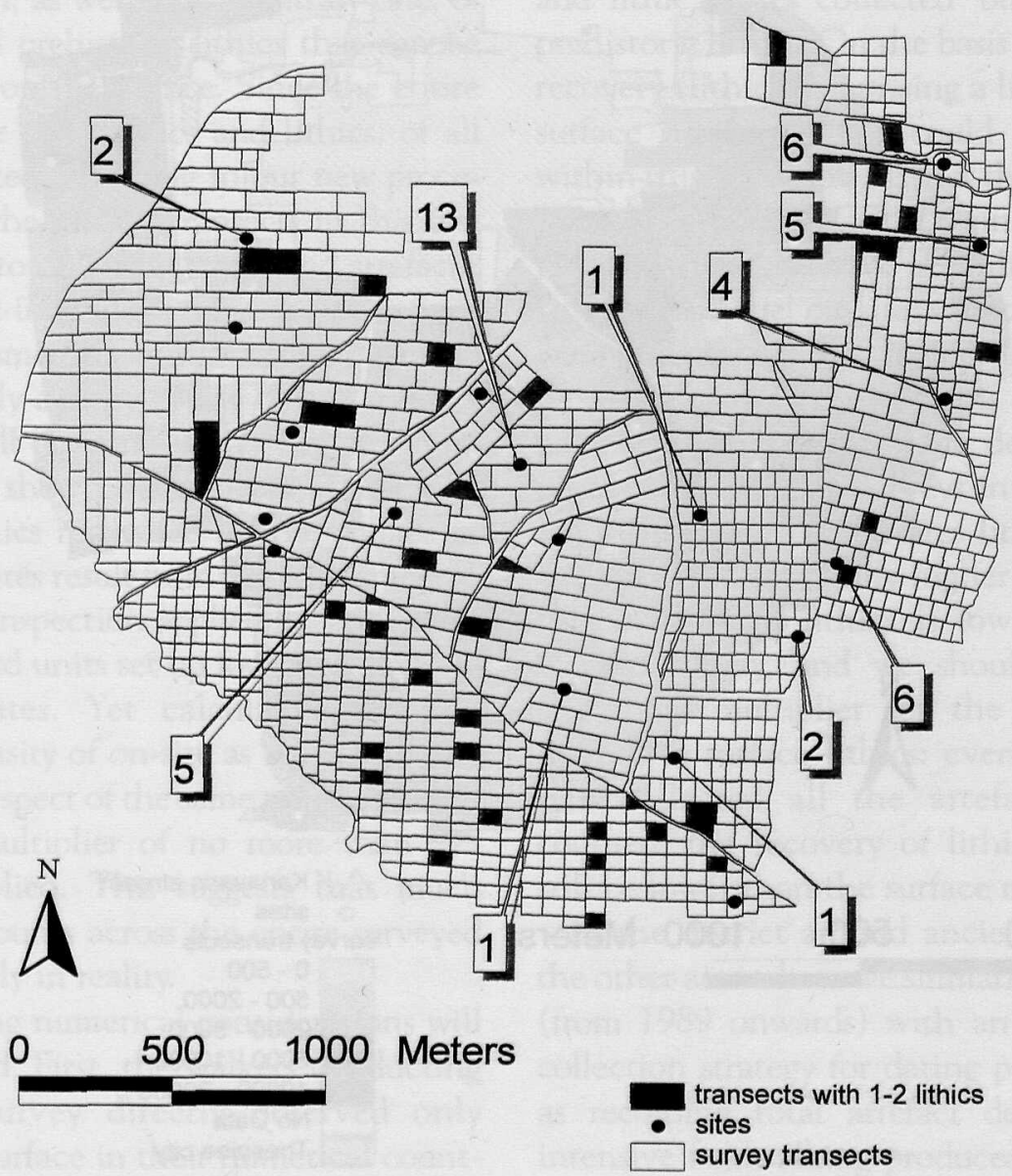

Figure 4. Fieldwalking transects in the LSE/THS sectors, adjacent to the ancient city of Thespiae, with transects containing 1-2 lithics from the dated sample collection of offsite finds shaded. Complementary finds of prehistoric lithics from the on-site sample collections at historical sites are shown as numbers of finds attached to each site location dot. 
(the relevant transects have shading keyed for finds density), together with another 46 lithic finds recovered during gridded collection on the 18 historical sites (shown as numbers of finds in boxes attached to site-location dots). No clear clustering is visible within the off-site lithic finds, apart from a slightly denser group by the Kanavaris stream in the northeast. Eleven out of the 18 putative historical sites, however, also yielded prehistoric lithics. As noted earlier, obsidian is rarely utilized in our region, in contrast to local chert, while the latter is almost impossible to observe when similar unworked stone litters the surface; fieldwalkers,

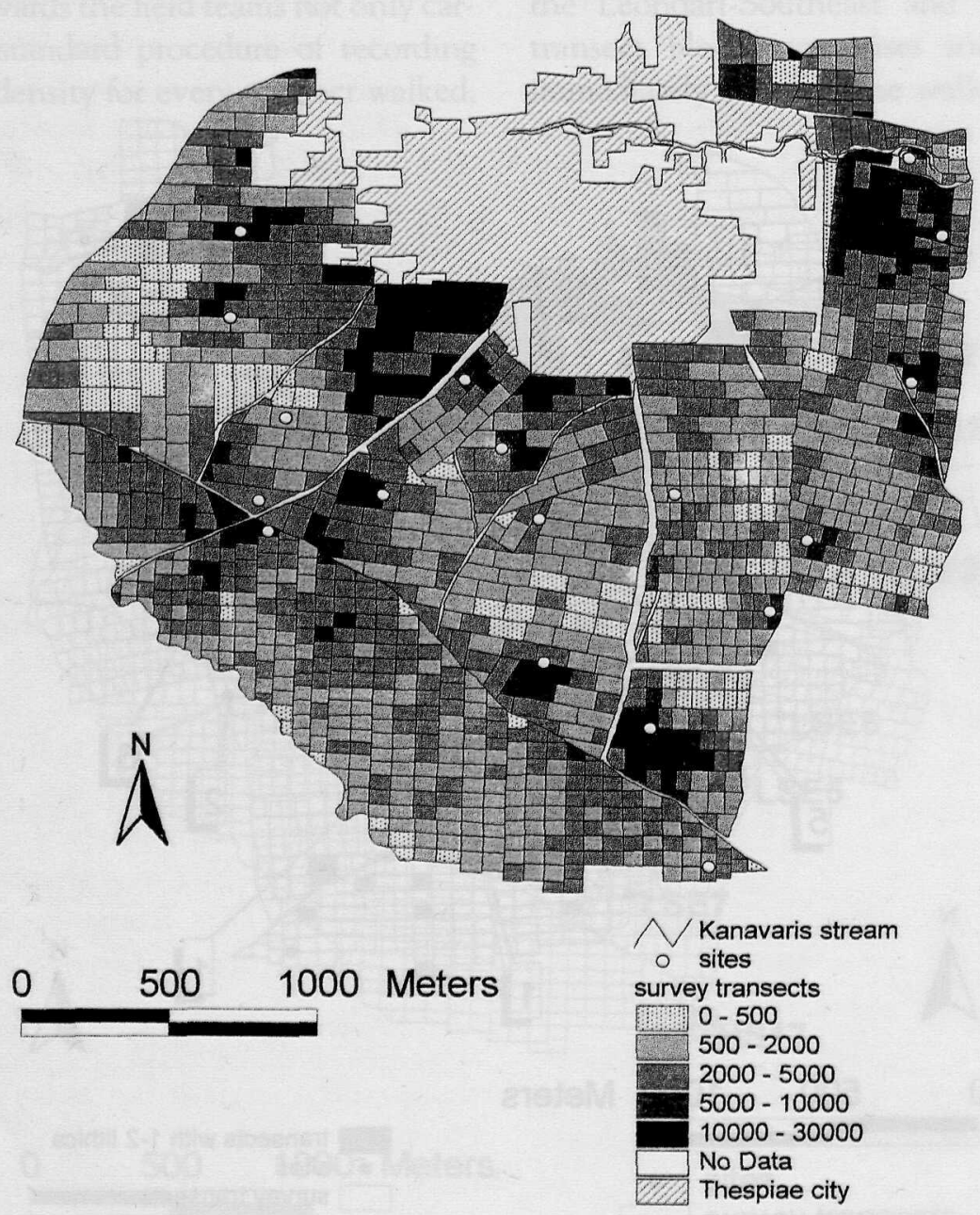

Figure 5. Fieldwalking transects in the LSE/THS sectors, adjacent to the ancient city of Thespiae. Reconstructed total density of surface finds, visibility-corrected (total 1.37 million potsherds and lithics). Key: density of surface finds per ha; identified rural sites shown as white circles. The sampling grid for the adjacent

- ancient city of Thespiae to the north is indicated by cross-hatching. 
too, are in general habituated to focusing on ceramics, to the exclusion of soil and its stone content. But in the two seasons in question (1989 and 1991), the vast majority of the lithics were found by one single fieldwalker, who had a trained eye for prehistoric lithics, but who could only cover one-fifth of the area walked. It is thus a safe inference that the number actually picked up was only a fraction of what might have been collected; and the recorded distribution is in turn probably a much smaller fraction, as well as an arbitrary one, of all the worked prehistoric lithics that can be assumed to lie on the surface. Since the entire artefact sample of ceramics and lithics, of all periods, collected according to our new procedure from all the off-site transects in this district, amounts to only a few thousand artefacts, when many an individual transect can boast a figure of the same order in its ceramic density count, the likely density of any type of artefact in this area will be immeasurably higher than the quantities shown. The larger numbers of prehistoric lithics recovered on the surface of the historical sites result from the greater intensity of surface inspection applied by field teams to the small grid units set up for sample collection across sites. Yet calculations of the increased intensity of on-site as against off-site recording, in respect of the same transects, indicate that a multiplier of no more than $2-3$ should be applied. This suggests that much higher lithic counts across the entire surveyed district are likely in reality.

The following numerical considerations will now be applied. First, the walkers conducting the off-site survey directly observed only $13.3 \%$ of the surface in their numerical counting of surface artefacts. Secondly, adjustment needs to be made for variations in visibility, based on vegetation cover, in each transect (cf. also Whitelaw 1991, for Keos). This means raising observed counts by a larger multiplier for each decrease in visibility level. When this is done, the total recorded density count of 95,895 artefacts rises by extrapolation to a total of between 1 and 1.5 million off-site surface pieces within this transect bloc as a whole, omitting the gridded site-collections (Figure 5). So, the small sample of some 3714 artefacts that the field-teams actually collected at the same time as recording the density can be used to estimate a plausible scale of total distribution by finds-category: the multiplier should be of the order of 270-400. Of the 3714 ceramic and lithic pieces collected 'off-site', 46 were prehistoric lithics. On the basis of proportional recovery (lithics comprising a little over $1 \%$ of surface artefacts), we could postulate that within this $5.2 \mathrm{sq} \mathrm{km}$ district there ought to be something between 12,500 and 18,500 lithic pieces that might have been brought back to base, had all the 'off-site' surface artefacts that were counted been collected: that is, between 24 and 35 pieces per ha. This density is comparable to prehistoric lithic densities of later prehistoric age from surveys in Southern England (Schofield [1987] cites lithic densities of 8-20 per ha, and locally higher). But in reality the visibility of lithics is low in a ceramicfocused survey, and we should envisage an additional multiplier for the suspected real density of surface lithics: even if fieldwalkers had collected all the artefacts that they counted, the recovery of lithic pieces would still be lower than the surface reality.

In the district around ancient Hyettos city, the other area where we similarly experimented (from 1989 onwards) with an off-site sample collection strategy for dating purposes, as well as recording total artefact density, standard intensive fieldwalking produced a similar density of lithic pieces collected. Here, however, we additionally deployed a lithic specialist to walk a $2 \mathrm{~m}$ strip behind the fieldwalking team in a sample sector, ignoring all ceramics, and found a density that would be extrapolated to 50 artefacts per ha, giving us a multiplier of 1.5 
between standard fieldwalking and expert search for lithics, at the same speed. This would imply a figure of between 19,000 and 27,000 lithic pieces for our $5.2 \mathrm{sq} \mathrm{km}$ block, to allow for the enhancement observed at Hyettos. As noted earlier, the arbitrary 'windows' of closer surface study, opened up through intensive collection across the historical sites of this district, provide further confirmation of a near-ubiquitous lithic carpet, as well as demonstrating how lithic recovery improves through increased attentiveness.

A density of this order of lithic pieces need not represent an unusually high level of discard. The (almost) indestructable nature of lithics would encourage very high cumulative totals, even for tools discarded on to the original landsurface. One cannot, in deference to earlier research (Runnels 1982), exclude the possibility of continued use of stone tools into historical times. But it does seem likely that this particular spread of lithics, invariably in the form of blades and small scrapers characteristic of the Neolithic and Bronze Ages, and usually of Melian obsidian, was mainly generated during prehistoric times by a small, initially hunter-gatherer and then predominantly mixed-farming population in this area, between say 8000 and $1500 \mathrm{BC}$. This would amount to up to four lithic artefacts a year; and even if only one family normally occupied this district, that would represent one lithic piece discarded per person per year. But there is a further factor to be incorporated. It has been calculated (Reynolds 1982) that in long-cultivated agricultural soils, especially those with a relatively stable geomorphology like Boeotia, something on the order of $16 \%$ of the ploughsoil assemblage is likely to be present on the surface at any one time, implying a likely multiplier, for the ploughsoil population to a depth of $20 \mathrm{~cm}$, of around six. For comparable investigations of the relationship between surface and sub-surface densities of artefacts, we have to move away from the Mediterranean area. Thus, research in Bohemia suggests a lower ratio of, typically, $5-15 \%$ surface finds to ploughsoil total (Kuna et al. 1993: 118; Kuna, in press). The total ceramic content of the ploughsoil to this depth in our selected district would therefore, on the first calculation, rise to some 6-9 million potsherds, and the lithic content-using the figure based on dedicated lithic fieldwalker recovery - to some 112,000 to 160,000 artefacts (or an average of 20-25 discards per year, six per person for a single nuclear family cultivating the area during farming prehistory). These figures, which would be even higher if the alternative estimates for the ratio of surface to subsurface were preferred, are not implausible activity-rates for an area of prime fertility (excellent soils, perennial water supplies; easy communications), such as the sector under study.

All of this underlines the surprising significance of the 50 or so lithic artefacts picked up by standard fieldwalking, implying a sustained and intense level of prehistoric activity in this district. The extrapolated surface density would be very much like that predicted from targeted surface lithic surveys in, for example, prehistoric lowland Britain, which has been described by John Schofield as virtually a continuous lithic carpet (Clark and Schofield 1991: 104). Indeed, where intensive lithic survey has been applied to a district of very focused prehistoric activity, as for example around Stonehenge (Richards 1990: 11), even the recorded lithic density may rise to well over 1000 pieces per ha. In Greece, too, maps generated by intensive survey (e.g. Cherry et al. 1991: 40-45, fig. 3.4) have shown a similar quality of continuity of spread, if naturally not (for the reasons just outlined) such high densities.

What would such a vastly denser lithic distribution represent in terms of prehistoric activity? Two things are well established in lithic studies: first, in contrast to prehistoric ceramics, lithics, 
while not wholly indestructible, are good survivors in the ploughsoil. Secondly, prehistoric farmers, herders and hunters made and deposited lithics in a wide variety of situations - on permanent and temporary/seasonal domestic sites and other activity foci, in burials, and during extramural work. In a fertile landscape subject to some six-and-a-half millennia of activity by hunter-gatherer and mixed-farming communities, such as lowland Boeotia, we would expect to find an almost continuous carpet of discarded lithic artefacts. Parallel research from intensive survey in Central Europe by the Institute of Archaeology in Prague (Kuna 1991; in press; Kuna et al. 1993; Salac 1995) has led to the insight that such widespread lithic scatters will emanate from two classes of taphonomic environments-pits, middens and burial structures or subsurface features currently being 'tapped' by ploughing; and palaeosols where artefacts were dropped or left on or near the surface of the soil and are now incorporated into the contemporary ploughsoil. What we are seeing, therefore, in Figure 4, is a minuscule fragment of a landscape of lithic deposition, combining finds from both prehistoric domestic and burial sites, and 'offsite' economic activities.

In contrast, the data shown in Figure 6 indicate the distribution of the 52 prehistoric ceramic finds collected within the off-site transect sample of 3714 surface artefacts (the relevant transects shaded by keyed numbers of finds), and the 25 prehistoric sherds collected during study of the historical sites (numbers of finds in boxes attached to site location dots). Here a different line of explanation has to be followed. According to the models of our Czech colleagues, importantly linking surface study to subsurface excavations at the same locations, these ceramics should emanate from a much narrower taphonomic context (Kuna 1991; 1998; in press; Kuna et al. 1993; Neustupny 1998; Salac 1995). Herein, indeed, lies the possibility of opening up a much greater number of windows of information onto our 'hidden prehistoric landscape' than are provided by those chance discoveries, and retrospective revaluations of historical sites, presented earlier. In the Czech Republic, as in Boeotia and in fact much of Europe, prehistoric ceramic assemblages are dominated by coarsewares, with a very low survival and recognition rate in the ploughsoil. For comparable distributions of prehistoric pottery produced by intensive survey to that shown here, the Prague team argue that only one of the two classes of taphonomic environment is likely to be responsible for virtually all the current surface ceramic finds. Prehistoric pottery deposited on the ancient surface or in the ploughsoil (e.g. by non-residential land-use discard, or through manuring with domestic refuse) would by now, almost without exception, have been destroyed through cultivation and natural weathering on the surface. What survives in today's ploughsoil has to be almost entirely derived, and that relatively recently, from a subsurface feature, a reservoir where it has avoided the more extreme destructive forces through long burial within an archaeological deposit-such as a pit, a ditch, a buried midden or a tomb. (For a closely comparable view, see the evidence from the Stonehenge Environs survey [Richards 1990: 25-30, 228-29, 280], and that from the A41 Project, also in England [McDonald 1993], and several other survey and excavation projects in England such as Maxey, Shiptonthorpe and Baldock [Jeremy Taylor, pers.com.] In Greece, Whitelaw [1991], in his analysis of the prehistoric surface material from Kephala and Paoura on Keos, has likewise argued for systematic degradation of prehistoric surface ceramics as opposed to lithics, suggesting that surface potsherds are therefore a more reliable indicator of underlying prehistoric deposits, as they would not survive significant displacement. Essentially, therefore, the distribution of Figure 6 should be that of prehistoric sub-surface struc- 
tures or sites. This quite revolutionary idea is at first sight counter-intuitive, as it has to be set against the extremely low numbers of pieces recorded and their almost unpatterned distribution across the landscape.
As we have seen, the low numbers are in fact entirely to be expected, first as a result of the low survival rate of prehistoric ceramics compared to those of historical age in the same ploughsoil assemblage, and secondly
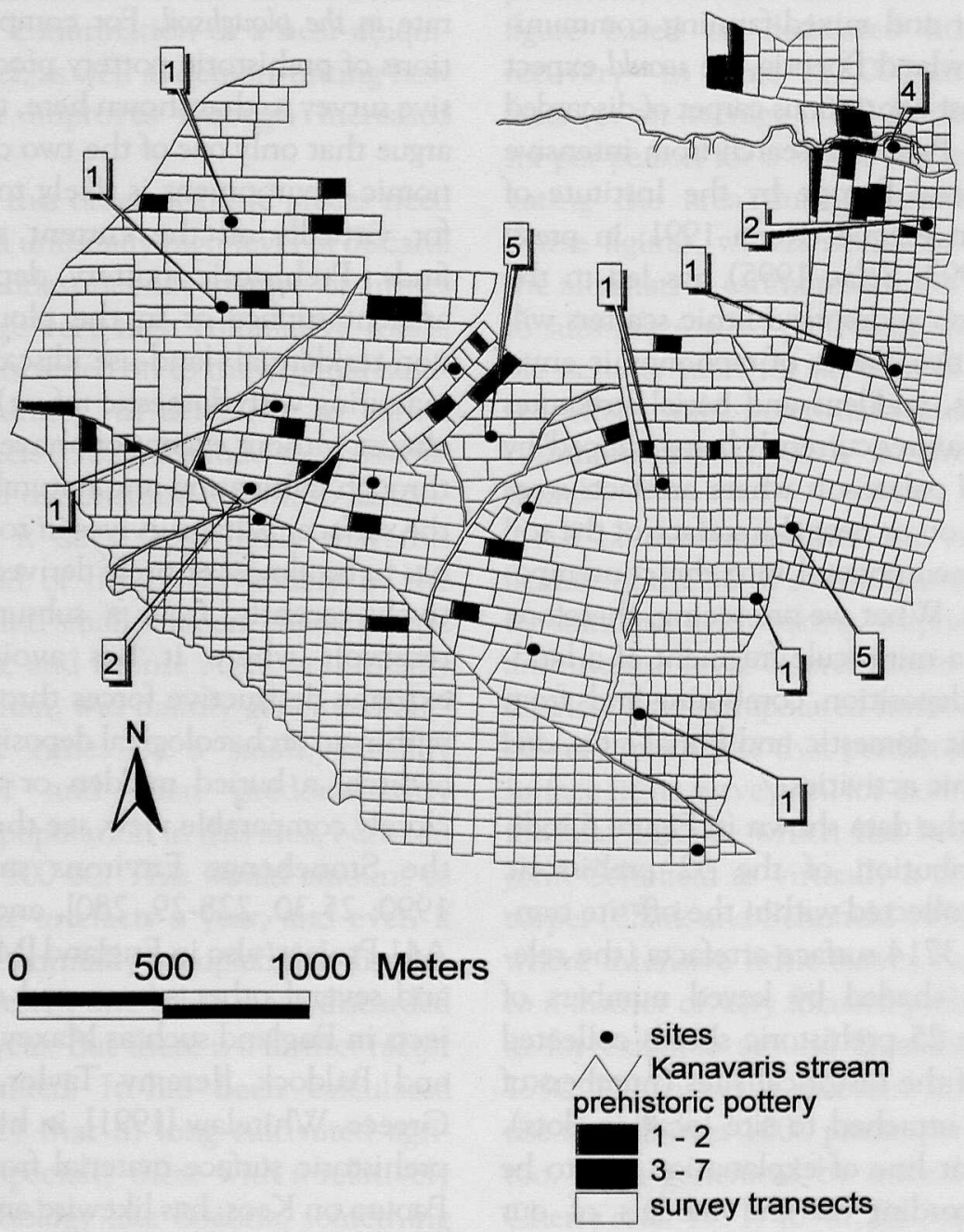

Figure 6. Fieldwalking transects in the LSE/THS sectors, adjacent to the ancient city of Thespiae. The location of all prehistoric ceramic finds identified within the sample collection from off-site fieldwalking is shown by transect (shaded by counts per transect, see key). Complementary on-site finds of prehistoric ceramics from the sample collections at historical sites are shown as numbers of finds attached to site location dots. 
because of the very low percentage of all surface ceramics collected for dating, compared with the absolute numbers to be found on the surface. Even the subsurface reservoirs of ceramics of prehistoric age have undergone massive destruction from weathering in prehistoric and later times, and we can suggest that in long-cultivated landscapes these subsurface features may be poor remnants of much richer and deeper pits and occupation features largely ploughed out long ago, or even secondary, residual deposits in structural artefact reservoirs of later periods (Kuna, in press; Salac 1995). The same $\mathrm{Czech}$ research shows that long-lived sites, or those with significant reoccupation, will serve as zones for the enhanced preservation of prehistoric pottery, through the physical sealing of earlier layers, or the reincorporation of older material into later structural features. Short-lived, single-phase sites with a dominance of coarser ceramics suffer far more severe degradation of their assemblages through prolonged cultivation and weathering of the land-surface overlying them, so widening the apparent contrast for the field surveyor confronted by the intuitively 'site-like' surface appearance of larger and/or multi-period settlement sites, in comparison to the seemingly insignificant scatter of a handful of prehistoric sherds representing a vestigial, short-lived farm-site or similar activity focus.

As was earlier demonstrated, justifiable extrapolation, even from the low numbers of prehistoric finds brought back in the selective sample collection throughout the Leondari South East and Thespiae South [LSE/THS] zone, allows us to infer a considerable lowdensity carpet across the entire survey sector. To what extent, however, is the low sample percentage of prehistoric as opposed to historic finds affected by the attitude and skills of the fieldwalkers, and in particular those on the Boeotia Project? The field teams were trained in advance in the appearance of prehistoric, Graeco-Roman and Mediaeval to Modern potsherds, and in how to collect onsite and in special off-site collections such as this one, samples of feature pot (rims, bases, handles), as well as a range of decorated wares and fabric types for body-sherds. Each team had an experienced leader providing quality control and advice on surface finds as they appeared. We will argue later in this paper that the statistical properties exhibited by prehistoric sherds and lithics in survey contexts other than 'traditional' denser findspots recognizably forming 'prehistoric sites', recur outside the Boeotia Project wherever similarly detailed and intensive recording has taken place, so that we feel justified in hypothesizing that the explanations for these phenomena are not confined to Boeotia, but may well be of much wider relevance in low land Greece. Likewise, although prehistoric coarseware may vary in other survey projects from being comparable to the ploughsoil porous softness of Boeotia ('wet-biscuit') to gritty toast (e.g. in Methana-Chris Mee, pers. com.), we would argue that the destructive forces of the weather and millennia of cultivation bring all such material into minimal surface quantities alike to each other, when it emanates from a short-lived farm or hamlet rather than from the much richer and far better conserved subsoil reservoirs to be associated with long-lived village settlements.

Once more, what would this distribution map for prehistoric finds - this time ceramic-look like if we were to attempt an extrapolation process? Working on the basis of proportional representation, we can suggest that were the entire $5.2 \mathrm{sq} \mathrm{km}$ to have been walked at $2 \mathrm{~m}$ intervals, and all counted finds collected, allowing for a visibility correction, Figure 6 would be displaying for the offsite transects alone something of the order of 19,000 prehistoric potsherds at a minimum (out of our extrapolated 
total surface ceramic of 1 to 1.5 million pieces). For the full depth of the ploughsoil, again, a multiplier of six or more to this figure could be postulated, to give a three-dimensional view to this distribution. Since we have argued that surface prehistoric ceramics are often 'invisible' to fieldwalkers in areas of dense historical-age pottery, or at least reduced to worn body-sherds of apparent undiagnosticity - unless (as at Askra) they too are found in dense concentrationsthis again must be a minimum, which would require a further significant multiplier, to envisage the actual density of the surviving surface prehistoric ceramics, were we able to see them during survey (there is on average one sherd for every four sq $\mathrm{m}$ of landsurface in this district, but $97 \%$ are recorded in sample collections as of historical age). For this reason, whenever John Bintliff and Oliver Dickinson revisited historical sites to enlarge the collection of a very sparse prehistoric component, the chief method was to lie full-length on the ground and inspect small areas by eye along the plane of the soil surface, seeking for the tell-tale 'wet biscuit' shapes and textures. A similar range of estimates to those we have made for missed lithics would be applicable to 'invisible' prehistoric coarseware.

It will be observed that no strong correlation yet appears between the admittedly tiny sample of lithics and that of prehistoric ceramics found and collected in offsite transects (Figures 4 and 6). Whether this could have been predicted on theoretical groundsin that the lithic scatter should reflect both on-site and off-site activity, but the pottery on-site activity only-it is noticeable that better correlation occurs in the (again) tiny sample of prehistoric finds from the collections on historical sites in the district: nine of the 18 historical sites sampled provided both prehistoric ceramics and lithics This must in part reflect the closer attention of fieldwalkers during collecting processes of a more inten- sive kind across gridded site surfaces.

The 'windows' opened up through gridded collection on the historical sites again provide confirmation of the ubiquitous presence of prehistoric ceramic, and hence of vestigial sites, throughout the district. Rather than seeing the locations of historic sites as 'special' also for prehistoric small-site locations, we are arguing that the recognition of lowdensity prehistoric artefact scatters is purely a mechanical result of the greatly enhanced attention given to the less conspicuous surface finds during on-site collection in these places. The 'reconstructed' pattern of prehistoric sherds would probably cover much of the landscape, but everywhere in small quantities. Again, we believe it appropriate to borrow from our Czech colleagues, this time their interpretative model for this striking landscape phenomenon. They have argued that such a widespread but thin carpet of prehistoric ceramics arises as the result of a process of continuous horizontal displacement of small farm and hamlet sites around fertile districts of the landscape over long periods of time. The likely explanation for recurrent relocation of small prehistoric rural sites (in clear contrast to the far rarer, larger, longerlived sites that comprise the traditional 'prehistoric site'), is a long-fallow system, where farmers shifted the location of their farms to rest soils and take advantage of less intensely cultivated areas in the vicinity, perhaps every few generations or even more frequently. House structures might last one to two generations, and arguably micro-locational shifts to closely adjacent field plots around a landscape of broadly similar agricultural potential would ultimately lead to an almost continuous distribution of surface artefacts, whose ceramic traces were rapidly reduced by later cultivation and weathering.

We must emphasize the considerable risks of chronological generalization based on sub- 
samples of the very tiny samples of prehistoric material collected on- and off-site in the LSE/THS sector. Yet a consistent pattern might be hypothesized on the data available, for further testing on a much larger sample. In contrast to the multi-period occupations characteristic for the 'prehistoric sites' found by both extensive and intensive survey on our own and other regional surveys in southern Greece, the prehistoric ceramics amenable to dating by phase from the rural sector in this present investigation, as so far studied, show the following statistics. The finds from historical site collections provided EBA from nine sites, MBA to LBA from three; the finds from off-site transects datable by phase were only of the EBA and LBA, the former predominating by about 3:1 over the latter. Very tentatively, we might suggest that small-site, shifting agriculture is especially important in the Final Neolithic-EBA. In the MBA and LBA, there is far more emphasis on larger settlement sites of hamlet-village size (none from this sector-but several ring our study district here--see Figure 7), alongside a less widespread small farm-site network in the countryside intervening between such minor foci.

Other surveys (e.g. Melos, Argolid, Methana) have produced similar on-site and off-site evidence for greater nucleation of settlement and a reduction in dispersed minor rural site activity between the EBA and MBA-LBA, which may become greatly enhanced if the implications of our reinterpretation of small prehistoric scatters were generalized. In southern England, Barrett (1994) has identified a similar long-term trend, contrasting a dominance of long-fallow shifting settlement systems leaving minimal artefact debris during the Neolithic and Early Bronze Age (fifth to third millennia $\mathrm{BC}$ ) (rarer larger and longlived foci excepted), with more stable nucleated settlement systems commencing in the Middle to Later Bronze Ages of the second millennium BC. The latter are marked by the creation of hierarchical formal field systems and are interpreted as representing a change to short-fallow, more intensive land use and a new emphasis on property rights. Closer to Greece, the Neothermal Dalmatia Survey Project (Chapman et al. 1996), in present-day Croatia, has evidenced a very dramatic reduction in identified small rural sites and 'off-site' transect finds between the Bronze Age and the Iron Age, in parallel with a marked transformation towards a more hierarchical political and settlement system in the region. Chapman and his colleagues (1996: 259-64) see the 'off-site' Bronze Age finds as indicative of either non-residential discard in a heavily utilized countryside, or the debris of a shortterm shifting settlement system much along the lines of the model favoured in this paper (indeed, the typical surface ceramics of later prehistoric Croatia, with their characteristic coarse fabrics, would in our view make the latter interpretation easily the most likely). The deeper social and ideological meanings drawn from this process of transformation in the landscape may therefore, in our opinion, offer important future insights into the formation of later Bronze Age hierarchical societies in lowland southern Greece (although, of course, it is not necessary to assume that such an implied pattern holds true everywhere in this region).

Two final observations might be made. First, it is quite possible that similar factors could be at work in later phases of landscape occupancy in southern Greece, if coarseware could be shown to have formed a dominant component in the domestic assemblage-for example, the 'Dark Age' of Sub-Mycenaean to earlier Geometric times, or the 'Dark Age' of the Early Byzantine centuries; if so, considerable revision would be required of present views on the location and density of population foci. Secondly, we have excluded from our range of 


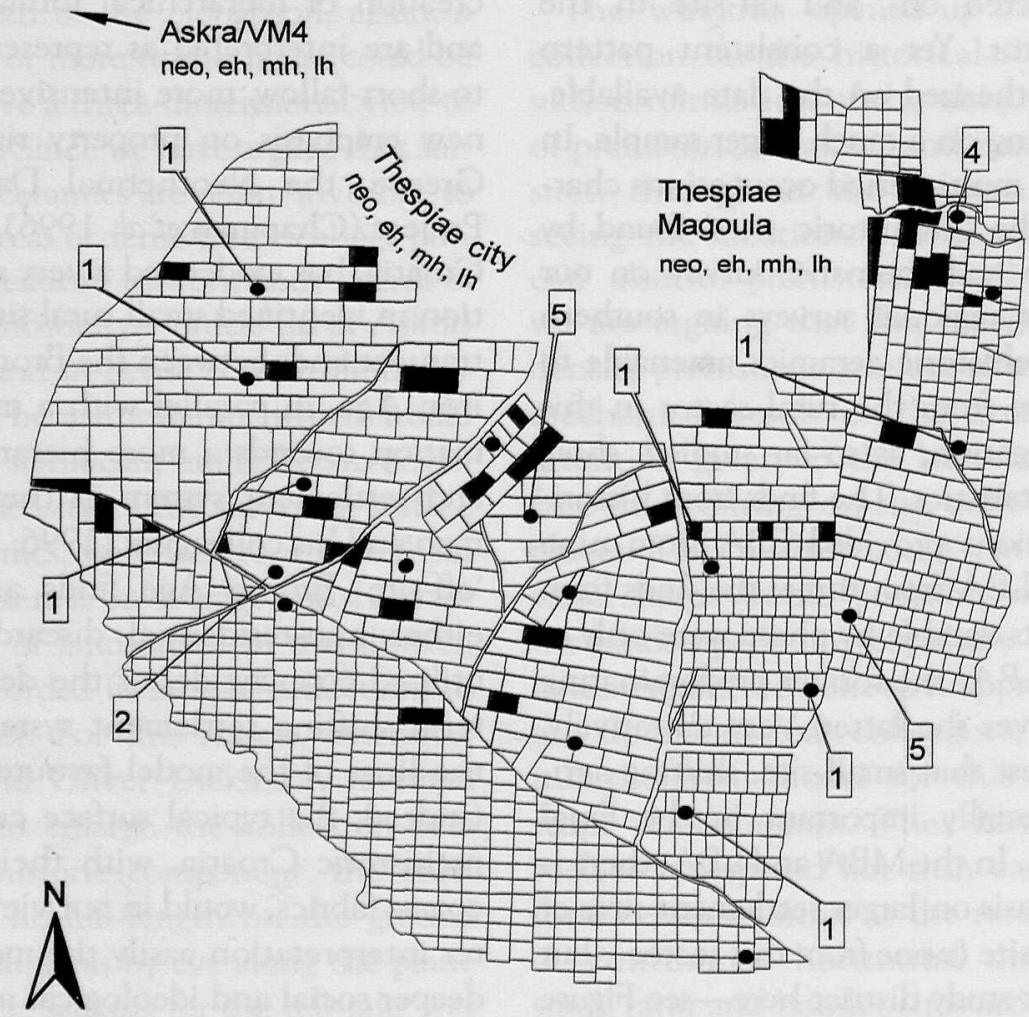

Palaeokarandas

- sites prehistoric pottery survey transects

Figure 7. Distribution of prehistoric ceramic finds from sample collections in the on-site (numbers per site in boxes) and off-site (shaded transects) areas of the LSE/THS sector, in relation to recognized prehistoric 'sites' in the surrounding district. The ancient city of Thespiae immediately adjoining this rural survey sector to the north has rich multi-period prehistoric material from the Magoula hillock (neo = Neolithic, $\mathrm{eh}=\mathrm{EBA}, \mathrm{mh}=\mathrm{MBA}, \mathrm{lh}=\mathrm{LBA})$ and also from the wider area of the city west of the Magoula. The Bronze Age settlement on the hill of Palaeokarandas is several hundred metres southeast of the outer limit of the rural survey sector and has finds of all three bronze age periods. The large prehistoric site at Askra is approximately $5 \mathrm{~km}$ west of ancient Thespiae city, and has Neolithic to LBA finds. 
analysis the possibility - indeed, likelihoodthat in certain periods of Greek prehistory and history the levels of ceramic production and consumption varied independently of simple population numbers (Millett 1991).

\section{The Hidden Landscape Uncovered: Impli- cations}

If we were to accept the entirely different picture of the surface traces of prehistoric settlement and related activity foci which has been put forward, it would provide us with a completely new way of making sense of intensive survey data. We have suggested that, at the very least, it will be worth testing in the rest of lowland Greece (the Pylos district included), the insights achieved over two decades in Boeotia, and over an equivalent period by our Czech colleagues, into the taphonomy of prehistoric surface sites. We shall therefore conclude this study by introducing relevant data from other recent intensive surface surveys in southern Greece, where a similar revisionary interpretation of prehistoric settlement activity might tentatively be hypothesized.

In a forthcoming study of Neolithic site evidence from Peloponnesian field surveys, Cavanagh (1999) reports that the Laconia Survey has identified some 12 locations with Final Neolithic-Early Bronze I evidence. Of these, just one findspot has significant artefact numbers, the rest consisting of very few sherds or merely lithic finds. Cavanagh suggests that the latter group could either represent locations without permanent occupation, orsignificantly-those where severe destruction of prehistoric ceramics has occurred.

On the Methana Survey, the authors report 51 findspots with EBA (Early Helladic [EH]) finds (Figure 8, from Mee and Forbes 1997: fig. 4.1). Twenty-five of these delivered more than five sherds of that period, and are considered to be full sites; almost half of these were also historic sites. The remaining $26 \mathrm{EH}$ ceramic findspots gave less than five diagnostic sherds (with five having only one recorded sherd). Mee and Forbes (1997: 42) suggest that the latter 26 findspots have insufficient finds to denote occupational status, especially given the strong local diagnosticity of $\mathrm{EH}$ coarseware, and should therefore be attributed to 'off-site' activity or 'scatter'. Nonetheless, they note the discordance between the location of some of these 'field' scatters and that of accepted 'sites'. Following the model proposed in the current paper, we would suggest that many if not most of the $26 \mathrm{EH}$ 'scatters' actually represent vestigial occupation sites of shifting settlement, small-site character. In the later Bronze Age periods, the following statistics are noteworthy (Mee and Forbes 1997: 51-53): for the MBA (Middle Helladic $[\mathrm{MH}])$, there were three findspots with more than five sherds, while one findspot had less than five sherds; all four had historic period finds on them. Nonetheless, the authors doubt the occupation status of all but one of the locations with more than five $\mathrm{MH}$ sherds, due to low find numbers. For the LBA (Late Helladic $[\mathrm{LH}]$ ) all eight findspots with $\mathrm{LH}$ sherds were also historic sites; there were five findspots with more than five LH sherds, while there were two further locations with a single LH sherd recovered.

We would be very much more positive concerning the site status of all the $\mathrm{MH}$ ceramic findspots, and underline the importance of the easier recognition of historic surface sites in leading to the recovery of associated prehistoric occupation in both $\mathrm{MH}$ and $\mathrm{LH}$. We suspect that a policy of continuous surface collection in transects would have yielded a far greater number of small scatters from all Bronze Age eras, as in Boeotia, but note the significant trend in the findspots recorded for settlement nucleation after the Early Bronze Age.

For the Keos Survey, the authors map an impressive number of findspots of lithics and prehistoric ceramic (Figure 9, from Cherry et 


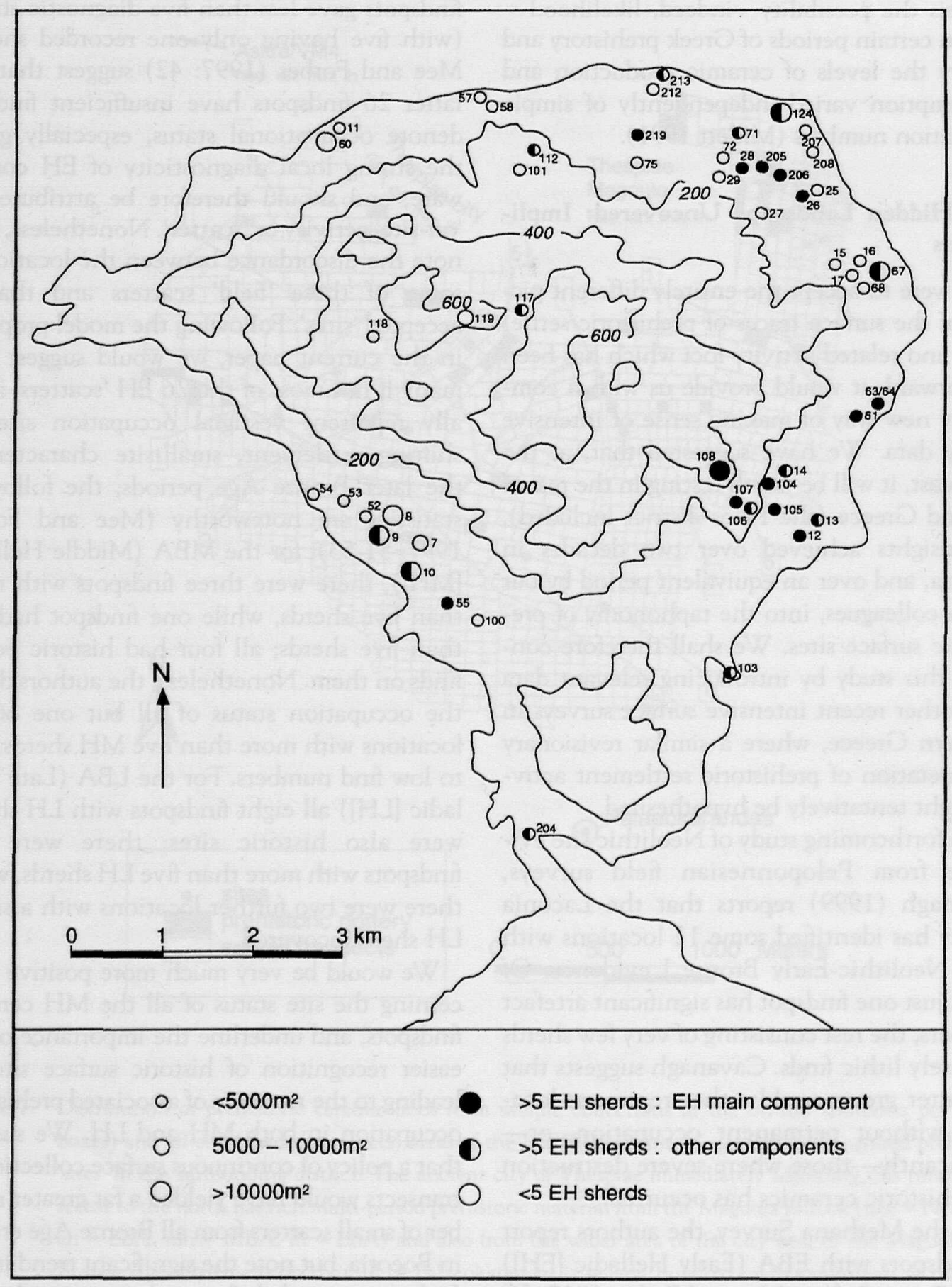

Figure 8. Methana Survey: findspots with EBA ceramics, distinguished by find quantity and overall site size (Mee and Forbes 1997: 44, fig. 4.1). 
al. 1991: 218, fig. 9.1; findspots without numbers mark transect scatters outside of identified 'sites' of historic or prehistoric date). Yet, tellingly, they state:

Virtually none of the sites in the survey area, other than Ayia Irini, Kephala, and Paoura, has produced substantial concentrations of prehistoric pottery or other finds. Indeed, at most locations, whether on-site or off-site... prehistoric activity is represented by less than a handful of pottery and at several by just a single positively diagnostic sherd... Such impoverished finds can scarcely be taken as indicative of the repeated use of a site, let alone its seasonal or permanent occupation, in prehistoric times (Cherry et al. 1991: 217).
Significantly, the three confirmed prehistoric settlement sites listed above were all known previous to the Keos survey, and (other than Ayia Irini) lack evidence of historical occupation, while of the remaining 24 prehistoric ceramic findspots, 18 are either historic sites or findspots where historic sherds outnumber those recognized of potential prehistoric date. Since off-site transect pottery was not collected systematically, and prehistoric sherds in particular were extremely rarely observed in fieldwalking (there are only three 'off-site' prehistoric pot scatters, two of which also have historic finds), our view would be that the very high rate of coincidence of the observed prehistoric pot scatters with the location of historic 'sites' is unlikely to be due to

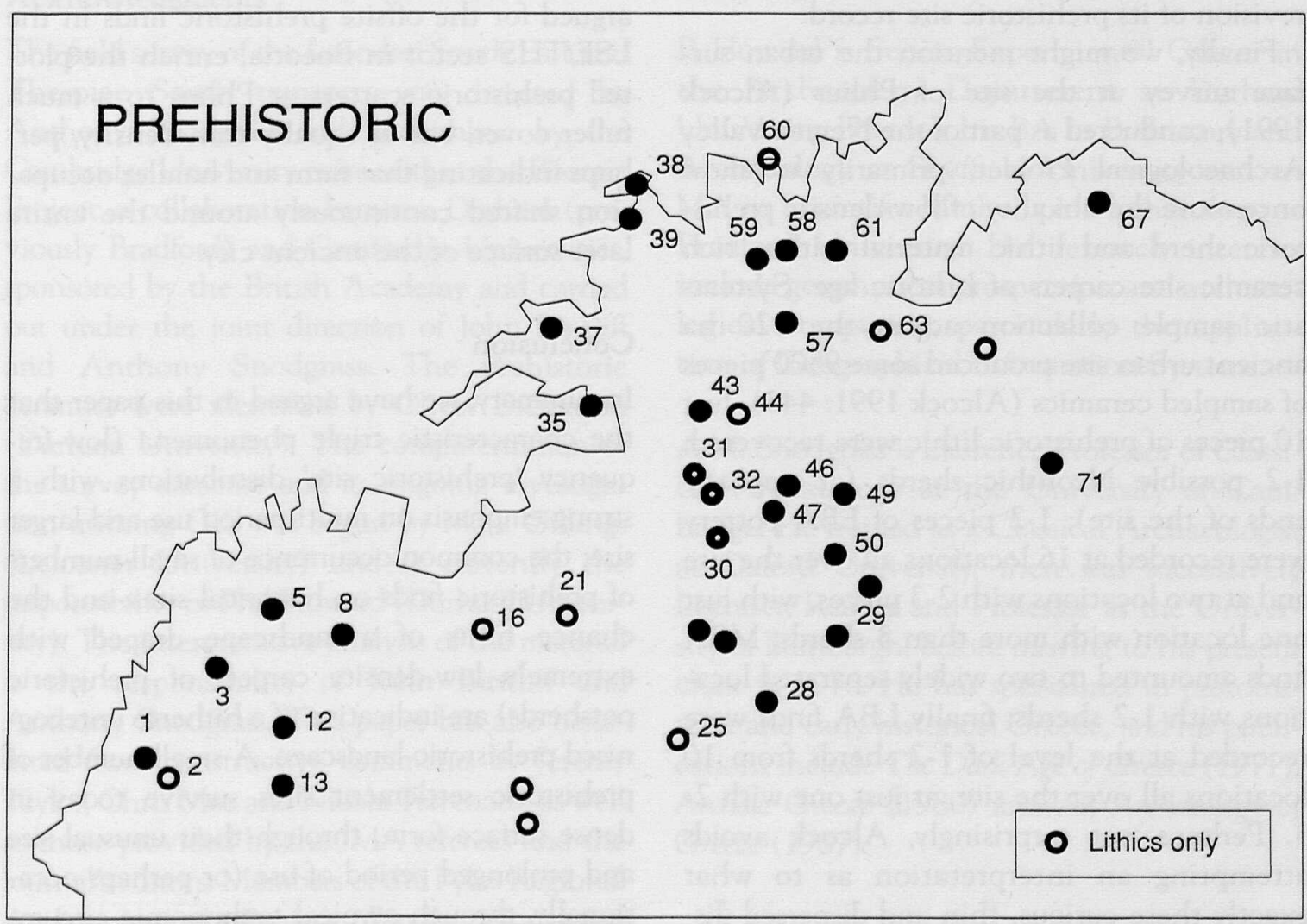

Figure 9. Northern Keos Survey: findspots with prehistoric ceramic or lithic artefacts (Cherry et al. 1991: 218, fig. 9.1). Unnumbered locations indicate tract, as opposed to on-site, finds. 
the repeated selection of a limited number of favourable activity locations, or proximity to coastal settlement nucleations (Cherry et al. 1991: 232, n. 1). We propose instead the mechanism already argued for from the Boeotian material, whereby the heightened visibility of historic pottery sites sets in motion a 'window' for the enhanced detection of far thinner prehistoric sherd scatters, which are in actuality dispersed more generally across the cultivable landscape. Were such exaggerated attention to surface finds as is given to 'sites' to be applied universally to the 'non-site' areas of north-west Keos, we believe that a far greater number of such prehistoric scatters would be revealed.

For the recent Pylos survey, we have already noted earlier the potential for a comparable revision of its prehistoric site record.

Finally, we might mention the urban surface survey at the site of Phlius (Alcock 1991), conducted as part of the Nemea Valley Archaeological Project, primarily to show once more the ubiquity of low-density prehistoric sherd and lithic material within rich ceramic site carpets of historic age. Systematic sample collection across the 120 ha ancient urban site produced some 9500 pieces of sampled ceramics (Alcock 1991: 443). Just 10 pieces of prehistoric lithic were recovered; 1-2 possible Neolithic sherds (at opposite ends of the site); $1-2$ pieces of EBA pottery were recorded at 16 locations all over the site and at two locations with 2-3 pieces, with just one location with more than 3 sherds; MBA finds amounted to two widely separated locations with $1-2$ sherds; finally LBA finds were recorded at the level of $1-2$ sherds from 10 locations all over the site, at just one with 2 3. Perhaps not surprisingly, Alcock avoids attempting an interpretation as to what exactly these curious, thin and dispersed distributions might represent in terms of prehistoric settlement, although she does seem to suggest that the LBA finds (as plentiful as for any other prehistoric phase) would hardly support village status.
In the light of our own and others' experience at other urban sites-such as Askra, mentioned earlier-we would agree with this view, but would also offer a model for the Bronze Age thin scatters: we suggest that the regular survival of sherds of all Bronze Age periods across the later Graeco-Roman urban zone points to the site being previously occupied by numerous, small and short-lived residential and burial areas, not necessarily ever representing a large contemporary population. Now since total surface ceramic density at this site can rise to as much as 5000 sherds per ha, a proportional extrapolation of the small prehistoric component within the sample dated collection of some 9500 sherds from the entire 120 ha site would, as we have argued for the offsite prehistoric finds in the LSE/THS sector in Boeotia, enrich the plotted prehistoric scatters at Phlius to a much fuller cover, but of equally thin density, perhaps indicating that farm and hamlet occupation shifted continuously around the entire later surface of the ancient city.

\section{Conclusion}

In summary, we have argued in this paper that the characteristic triple phenomena (low-frequency 'prehistoric site' distributions with a strong emphasis on multi-period use and larger size; the common occurrence of small numbers of prehistoric finds on historical sites; and the chance hints of a landscape draped with extremely low-density carpets of prehistoric potsherds) are indicative of a hitherto unrecognized prehistoric landscape. A small number of prehistoric settlement sites survive today in dense surface form, through their unusual size and prolonged period of use (or perhaps occasionally, through atypical taphonomic circumstances having prevented an earlier exposure to intensive plough damage or natural surface weathering). But by far the majority of prehistoric settlements were small sites of farm or hamlet character, whose vestigial ceramic 
traces are usually not noted at all in intensive survey; if they are, through the double action of rare transect collection and indirect discovery within historical site collection, then numerically their contribution to surface density is so slight that their one- or two-piece presence on the surface as recorded attracts no special interest. In Messenia, as in Boeotia and the other Greek survey regions discussed in this article, just as in Bohemia, these sporadic finds of a few fragments represent the tip of a giant iceberg of many thousands of small and ephemeral occupation- and activity-foci, shifting within small areas of landscape, across the millennia of farming prehistory.

\section{Acknowledgments}

The field survey of the Leondari South East and Thespiae South transects was directed by Anthony Snodgrass and undertaken by the Cambridge University team within the Boeotia Project, a collaboration between Durham (previously Bradford) and Cambridge Universities, sponsored by the British Academy and carried out under the joint direction of John Bintliff and Anthony Snodgrass. The prehistoric ceramics were identified by Oliver Dickinson (Durham University). The computerization of the survey database and its ongoing investigation utilizing GIS was begun by Mark Gillings (Leicester University) and is currently the responsibility of Phil Howard (Durham University). The interpretative analysis of the material is the responsibility of John Bintliff and Anthony Snodgrass. This paper has also benefitted from constructive comments by Jeremy Taylor, Chris Mee and Nicola Terrenato, as well as those provided by the JMA referees and the journal's editors. Members of the Pylos Regional Archaeological Project kindly elucidated aspects of their preliminary publications. The invitation to John Bintliff to undertake a study visit to the Institute of Archaeology in Prague was a major catalyst in the making of this paper.

\section{About the Authors}

J.L.Bintliff is Professor of Classical Archaeology at the University of Leiden. He was trained as a prehistorian at Cambridge by David Clarke and E.S. Higgs, and has been successively Lecturer and Reader in Archaeology at the University of Bradford and Reader at the University of Durham. His publications include Natural Environment and Human Settlement in Prehistoric Greece (1977), European Social Evolution: Archaeological Perspectives (1984), The Annales School and Archaeology (1991), Europe Between Late Antiquity and the Middle Ages (with $\mathrm{H}$. Hamerow) (1995), and Structure and Contingency in the Evolution of Life, Human Evolution and Human History (1999).

P. Howard is Senior Experimental Officer in the Archaeology Department at Durham University. He took his BA in Prehistory and Archaeology at Sheffield University and an MA in Scientific Methods in Archaeology at Bradford University. His research interests include geophysical prospection and archaeological computing, particularly the application of Geographical Information Systems.

A.M. Snodgrass is Laurence Professor of Classical Archaeology at the University of Cambridge. He trained as a Classical Archaeologist at Oxford University, then was successively Lecturer, Reader and Professor at the University of Edinburgh, before moving to his present chair in 1976. He has specialized in protohistoric and early historical Greece, and his publications include The Dark Age of Greece (1971), Archaic Greece (1980) and An Archaeology of Greece (1987).

\section{References}

Alcock, S.E.

1991 Urban survey and the polis of Phlius. Hesperia 60: 421-63. 
Barrett, J.C.

1994 Fragments of Antiquity: An Archaeology of Social Life in Britain, 2900-1200 BC. Oxford: Blackwell.

Bintliff, J.L.

1977a Natural Environment and Human Settlement in Prehistoric Greece. BAR International Series 28. Oxford: British Archaeological Reports.

1977b New approaches to human geography. Prehistoric Greece: a case study. In F. Carter (ed.), An Historical Geography of the Balkans, 59. 114. London: Academic Press.

1985 The Boeotia Survey, Central Greece. In S. Macready and F.H. Thompson (eds.), Archaeological Field Survey in Britain and Abroad, 196216. London: Society of Antiquaries.

1991 The Roman countryside in Central Greece: observations and theories from the Boeotia Survey (1978-1987). In G. Barker and J. Lloyd (eds.), Roman Landscapes: Archaeological Survey in the Mediterranean Region, 122-32. London: British School at Rome.

1996 The archaeological survey of the Valley of the Muses and its significance for Boeotian History. In A. Hurst and A. Schachter (edis.), La Montagne des Muses, 193-224. Geneva: Librairie Droz.

1997a The archaeological investigation of deserted medieval and post-medieval villages in Greece. In G. De Boe and F. Verhaeghe (eds.), Rural Settlements in Medieval Europe. Papers of the 'Medieval Europe Brugge 1997' Conference, vol. 6: 21-34. Bruges: Zellik.

$1997 \mathrm{~b}$ Further considerations on the population of ancient Boeotia. In J.L. Bintliff (ed.), Recent Developments in the History and Archaeology of Central Greece. BAR International Series 666: 231-52. Oxford: Tempus Reparatum.

1997c Regional survey, demography, and the rise of complex societies in the ancient Aegean: coreperiphery, neo-malthusian, and other interpretive models. Journal of Field Archaeology 24: $1-38$.

Bintliff, J.L., and A.M. Snodgrass

1985 The Boeotia survey, a preliminary report: the first four years. Journal of Field Archaeology 12: 123-61.

1988a Off-site pottery distributions: a regional and interregional perspective. Current Anthropology 29: 506-13. 1988b The end of the Roman countryside: a view from the East. In R.F.J. Jones, J.H.F. Bloemers, S.L. Dyson and M. Biddle (eds.), First Millennium Papers:Western Europe in the First Millennium AD. BAR International Series 401: 175-217. Oxford: British Archaeological Reports.

Blackman, D., and K. Branigan

1977 An archaeological survey of the Ayiofarango valley. Annual of the British School at Athens 72: $13-84$.

Cavanagh, W.G.

1999 Revenons à nos moutons: surface survey and the Peloponnese in the Late and Final Neolithic. In J. Renard (ed.), Le Péloponnèse: Archéologie et histoire, 31-65. Rennes: Presses: Universitaires Rennes.

Chapman, J., R. Shiel and S. Batovic

1996 The Changing Face of Dalmatia. Archaeological and Ecological Studies in a Mediterranean Landscape. London: Cassell and Leicester University Press.

Carothers, J., and W.A. McDonald

1979 Size and distribution of the population in Late Bronze Age Messenia: some statistical approaches. Journal of Field Archaeology 7: 433-54.

Cherry, J.F.

1979 Four problems in Cycladic prehistory. In J.L. Davis and J.F. Cherry (eds.), Papers in Cycladic Prehistory. Monograph 14: 22-47. Los Angeles: UCLA Institute of Archaeology.

1982 A preliminary definition of site distribution on Melos. In C. Renfrew and M. Wagstaff (eds.), An Island Polity: The Archaeology of Exploitation in Melos, 10-23. Cambridge: Cambridge University Press.

1983 Frogs round the pond: perspectives on current archaeological survey projects in the Mediterranean region. In D.R. Keller and D.W. Rupp (eds.), Archaeological Survey in the Mediterranean Area. BAR International Series 155: 375-416. Oxford: British Archaeological Reports.

1984 Common sense in Mediterranean survey? Journal of Field Archaeology 11: 117-20.

Cherry, J.F., J.L. Davis and E. Mantzourani

1991 Landscape Archaeology as Long-Term History: Northern Keos in the Cycladic Islands. Monumenta Archaeologica 16. Los Angeles: UCLA Institute of Archaeology. 
Clark, R.A., and A.J. Schofield

1991 By experiment and calibration: an integrated approach to archaeology of the ploughsoil. In A.J. Schofield (ed.), Interpreting Artefact Scatters: Contributions to Ploughsoil Archaeology, 93-105. Oxford: Oxbow.

Davis, J.L., S.E. Alcock, J. Bennet, Y.G. Lolos and C.W. Shelmerdine

1997 The Pylos Regional Archaeological Project. Part I: Overview and the archaeological survey. Hesperia 66: 391-494.

Davis, J.L. (ed.)

1998 Sandy Pylos: An Archaeological History from Nestor to Navarino. Austin: University of Texas Press.

Di Gennaro, F., and S. Stoddart

1982 A review of the evidence for prehistoric activity in part of South Etruria. Papers of the British School at Rome 50: 1-21.

Hope Simpson, R.

1984 The analysis of data from surface surveys. Journal of Field Archaeology 11: 115-17.

1985 The evaluation of data from surface surveys. Journal of Field Archaeology 12: 258-60.

Jacobsen, T.W.

1984 Seasonal pastoralism in Southern Greece: a consideration of the ecology of Neolithic Urfirnis pottery. In P.M. Rice (ed.), Pots and Potters: Current Approaches in Ceramic Archaeology, 27-43. Los Angeles: UCLA Institute of Archaeology.

Jameson, M.H., C.N. Runnels and T.H. van Andel

1994 A Greek Countryside: The Southern Argolid from Prehistory to the Present Day. Stanford: Stanford University Press.

Kuna, $\mathrm{M}$.

1991 The structuring of prehistoric landscape. Antiquity 65: 332-47.

1998 The memory of landscapes. In E. Neustupny (ed.), Space in Prehistoric Bohemia, 106-115. Prague: Institute of Archaeology.

In press Surface artefact studies in the Czech Republic. In J. Bintliff, M. Kuna and N.Venclova (eds.), The Future of Archaeological Field Survey in Europe. Sheffield: Sheffield Academic Press.

Kuna, M., M. Zvelebil, P.J. Foster, and D. Dreslerova

1993 Field survey and landscape archaeology research design: methodology of a regional field survey in Bohemia. Pamatky Archeologicke 84(2): 110-30.

McDonald, $T$.

1993 The A41 Excavations. Current Archaeology 136: $133-37$.

McDonald, W.A.

1984 The Minnesota Messenia Survey: a look back. In A.L. Boegehold et al. (eds.), Studies Presented to Sterling Dow. Greek, Roman, and Byzantine Studies Monograph 10: 185-91. Durham, NC: Duke University Press.

McDonald, W.A., and G.R. Rapp, Jr (eds.)

1972 The Minnesota Messenia Expedition: Reconstructing a Bronze Age Regional Environment. Minneapolis: University of Minnesota Press.

Mee, C., and H. Forbes (eds.)

1997 A Rough and Rocky Place: The Landscape and Settlement History of the Methana Peninsula, Greece. Liverpool Monographs in Archaeology and Oriental Studies. Liverpool: Liverpool University Press.

Millett, $M$.

1991 Pottery: population or supply patterns? In G. Barker and J. Lloyd (eds.), Roman Landscapes: Archaeological Survey in the Mediterranean Region, 18-26. London: British School at Rome.

Neustupny, E.

1998 The transformation of community areas into settlement areas. In E. Neustupny (ed.), Space in Prehistoric Bohemia, 45-61. Prague: Institute of Archaeology.

Pope, K.O, and T.H. van Andel

1984 Late Quaternary alluviation and soil formation in the southern Argolid. Journal of Archaeological Science 11: 281-306.

Renfrew, C., and M. Wagstaff (eds.).

1982 An Island Polity: The Archaeology of Exploitation in Melos. Cambridge: Cambridge University Press.

Reynolds, P.

1982 The ploughzone. In Anon (ed.), Festschrift zum 100 jährigen Jubiläum der Abteilung Vorgeschichte der naturhistorischen Gesellschaft Nümberg, 315. 40. Nuremberg.

Richards, J. (ed.).

1990 The Stonehenge Environs Project. London: Historic Buildings and Monuments Commission for England. 
Runnels, C.N.

1982 Flaked-stone artifacts in Greece during the historical period. Journal of Field Archaeology 9: 363-73.

Rutter, J.B.

1983 Some thoughts on the analysis of ceramic data generated by site surveys. In D.R. Keller and D.W. Rupp (eds.), Archaeological Survey in the Mediterranean Area. BAR International Series 155: 137-42. Oxford: British Archaeological Reports.

Salac, V.

1995 The density of archaeological finds in settlement features of the La Tène period. In M. Kuna and N. Venclova (eds.), Whither Archaeology? Papers in Honour of Evzen Neustupny, 264-76. Prague: Institute of Archaeology.

Schofield, A.J.

1987 The role of palaeoecology in understanding variations in regional survey data. Circaea 5 : 33-42.

Shelmerdine, C.W.

1997 Review of Aegean Prehistory VI: The Palatial
Bronze Age of the southern and central Greek Mainland. American Journal of Archaeology 101: 537-85.

Snodgrass, A.M.

1987 An Archaeology of Greece. Berkeley and Los Angeles: University of California Press.

Wagstaff, M., and J.F. Cherry

1982 Settlement and population. In C. Renfrew and M. Wagstaff (eds.), An Island Polity: The Archaeology of Exploitation on Melos, 136-55. Cambridge: Cambridge University Press.

Whitelaw, T.M.

1991 Investigations at the Neolithic sites of Kephala and Paoura. In J.F. Cherry, J.L. Davis and E. Mantzourani, Landscape Archaeology as Long-Term History: Northern Keos in the Cycladic Islands. Monumenta Archaeologica 16: 199-216. Los Angeles: UCLA Institute of Archaeology.

Zangger, E., M.E. Timpson, S.B. Yazvenko, F. Kuhnke and J.Knauss

1997 The Pylos Regional Survey Project. Part II: landscape evolution and site preservation. Hesperia 66: 549-641. 